\title{
Stratigraphic and Facies
}

Relationships of the

Carys Mills Formation of

Ordovician and Silurian Age

Northeast Maine

$\begin{array}{lllll}\text { GE LOGICAL SURVEY BULLETIN } & 1264\end{array}$ 


\section{Stratigraphic and Facies}

Relationships of the

Carys Mills Formation of

Ordovician and Silurian Age

Northeast Maine

By LOUIS PAVLIDES

GE OLOGICAL S U R VEY B U L LET I N 1264

A discussion of temporal and

lateral equivalence of Ordovician and Silurian sedimentary rocks

in northeast Maine

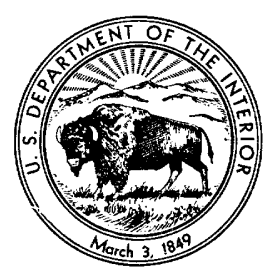




\title{
UNITED STATES DEPARTMENT OF THE INTERIOR STEWART L. UDALL, Secretary
}

\author{
GEOLOGICAL SURVEY \\ William T. Pecora, Director
}

Library of Congress catalog-card No. GS 68-241 


\section{CONTENTS}

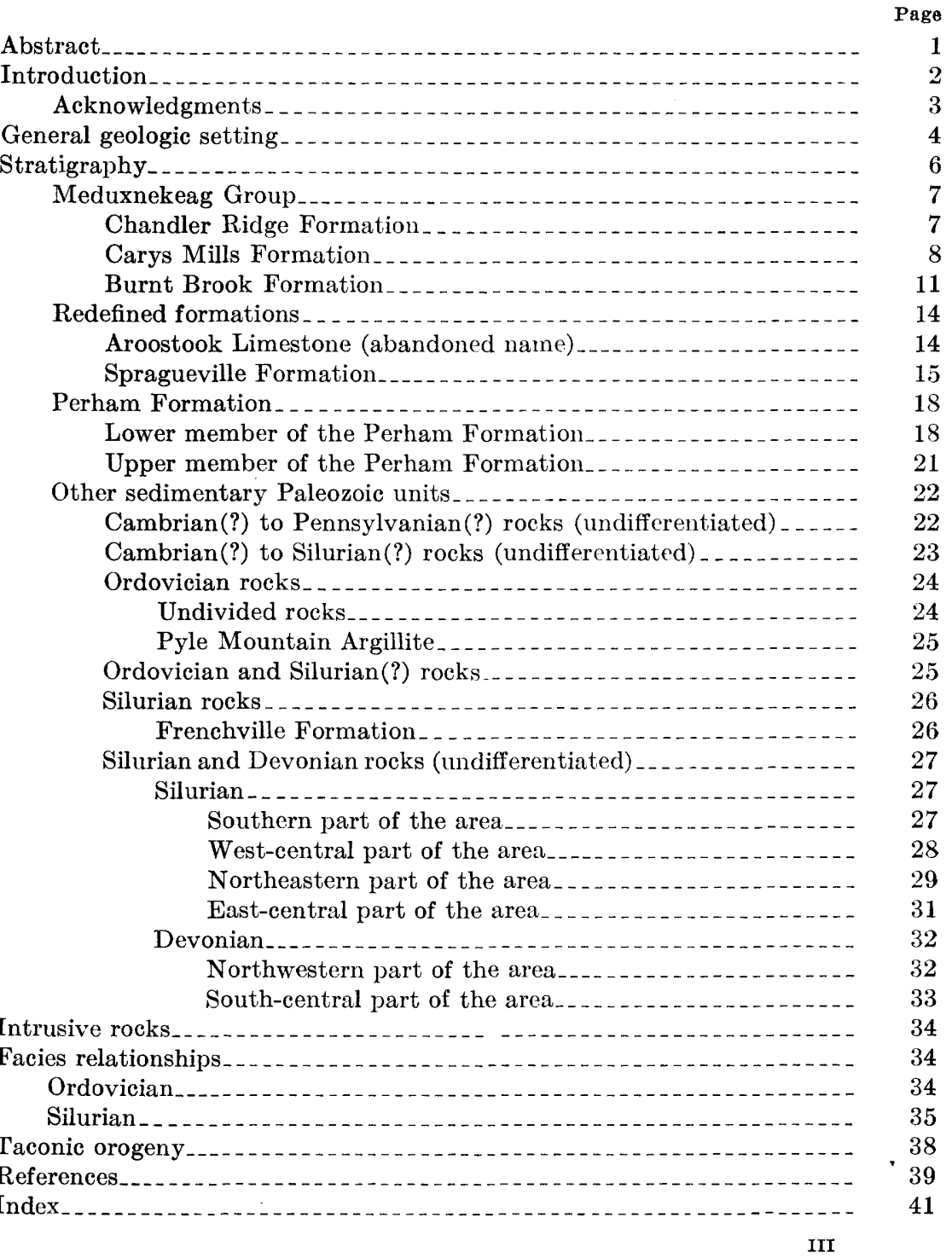




\section{ILLUSTRATIONS}

Plate 1. Bedrock geologic map of northeastern Maine and northwestern New Brunswick ..... . . . .

Figure 1. Index map of Maine and adjoining Canada...

2. Section showing generalized facies relationships before deformation of the Carys Mills Formation and other formations between South Brook and East Hodgdon areas, Maine.....

3. Section showing generalized facies relationships before deformation of the Carys Mills Formation and other formations between the Castle Hill and Fort Fairfield areas, Maine....

\section{TABLES}

TABLE 1. Comparison of the Meduxnekeag Formation of former usage

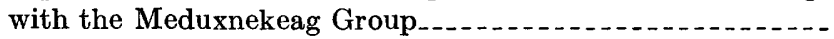

2. Summary of revisions of superposition, chronology, and nomenclature in the Aroostook Limestone of former usage in northern Maine.... 7

3. Fossil localities within the Carys Mills Formation........ 


\title{
STRATIGRAPHIC AND FACIES RELATIONSHIPS OF THE GARYS MILLS FORMATION OF ORDOVICIAN AND SILURIAN AGE, NORTHEAST MAINE
}

\author{
By Louis Pavlides
}

\section{ABSTRACT}

The Carys Mills Formation in northeastern Maine is primarily a ribbon limestone sequence that ranges in thickness from about 1,500 to at least 12,000 feet and that spans Middle Ordovician (graptolite zone 13) to Early Silurian (graptolite zone 19) times. It grades upward into the younger Smyrna Mills Formation, and probably also into the Perham Formation, both of Silurian age, indicating that the basin in which it was deposited was one of uninterrupted sedimentation during the interval of the Taconic disturbance. Locally, the Carys Mills is underlain by the Chandler Ridge Formation that is composed typically of graywacke and slate, is about 5,000 feet thick, and is of Ordovician ( ?) age. The Burnt Brook Formation, a slate unit also about 5,000 feet thick, locally overlies the Carys Mills and is of Silurian (?) age and is probably coeval, in part, with the Smyrna Mills Formation.

The rocks of Middle Ordovician age of the Carys Mills are the calcareous equivalents of Middle Ordovician eugeosynclinal suites of rocks that occur west of the outcrop belt of the Carys Mills. The Pyle Mountain Argillite of Late Ordovician age is also a western temporal equivalent of part of the Carys Mills.

The Silurian time equivalents of the Carys Mills include the lower member of the Perham Formation of early Llandovery to late Wenlock age, into which the Carys Mills wedged out to the west at about early middle Llandovers time. The Spragueville Formation, an eastern temporal equivalent, in part, of the lower member of the Perham, ranges in age from Early silurian (graptolite zone 19) at its base in its eastern outcrop belt to late Llandovery $\mathbf{C}_{4}-\mathrm{C}_{5}$ in its western outcrop belt, where it eventually wedges out. The Spragueville is thin in its western exposures and also appears to be jounger there than to the east. The Spragueville is the temporal equivalent of the upper part of the Carys Mills and parts of the lower member of the Perham. It is the more offshore time equivalent of the Frenchville Formation of $\mathrm{C}_{4}-\mathrm{C}_{5}$ age, a unit whose graywacke and conglomerate beds reflect a local event of Taconic uplift in this region of the northern Appalachians. 


\section{INTRODUCTION}

A distinctive suite of calcareous rocks characterize the core of the Aroostook-Matapedia anticlinorium, a regional feature that extends from northeastern Maine across northern New Brunswick to Perce, Quebec. Local names are used for these rocks at different places within the anticlinorium. Along the southern part of the Gaspé Peninsula of Quebec, the Matapedia Group (Crickmay, 1932; Beland, 1958, 1960), Pabos Formation (Kindle, 1935), and the Whitehead Formation (Schuchert and Cooper, 1930) constitute this suite. These rocks are generally unnamed in New Brunswick, and their precise distribution is not well known across the northern part of the province. In Maine, rocks of this suite were assigned to the ribbon limestone member of the Aroostook Limestone (White, 1943, p. 129) and to the ribbon rock member of the Meduxnekeag Formation (Pavlides, 1962, p. 11-12; 1965, p. 14-20). More recently the Meduxnekeag Formation was elevated to group rank, the Aroostook Limestone was abandoned as a stratigraphic name, and the ribbon limestone or ribbon rock of former usage was assigned to the Carys Mills Formation (Pavlides, 1966b).

The stratigraphic nomenclature for rocks formerly assigned to the Meduxnekeag Formation and the Aroostook Limestone was only briefly discussed when these stratigraphic names were modified. The first part of this report (stratigraphy) more fully describes this revised nomenclature and some of the stratigraphy of closely related formations. Some other Paleozoic rocks of the region have been lumped into broad stratigraphic units, and some formations are described only briefly herein. This procedure is particularly true for Devonian and younger rocks only incidentally related to the stratigraphic problems of the Ordovician and Silurian rocks that are the main concern of this report. These other Paleozoic rocks are discussed separately in a succeeding part of the report. Finally, a general discussion of the stratigraphic and facies relationships of the Ordovician and Silurian units is given.

Much of the nomenclature used for age designations herein is based on the European standard section (see Pavlides and Berry, 1966, table 3; Pavlides and others, 1964, p. C29).

The names Carys Mills and Smyrna Mills Formations are herein extended into contiguous terrane of northwestern New Brunswick (pl. 1), based on reconnaissance geologic mapping there (Pavlides, 1966a). This mapping was carried out to obtain a better understanding of some of the geologic problems in Maine by (1) defining the eastern boundary of the Carys Mills Formation in adjoining New Brunswick and (2) reconciling differences between the writer's mapping in Maine and 
that of Anderson (1954a, 1956) and Anderson and Poole (1959) in contiguous New Brunswick. This reconnaissance (Pavlides, 1966a) yielded a different stratigraphic sequence and structural framework for the Woodstock and Coldstream areas of New Brunswick than had been mapped earlier by Anderson (1954a, 1956). In general, this geologic model is now also recognized in New Brunswick by Anderson (written commun., Dec. 1965), with minor differences as to the position of contacts between some of the stratigraphic units.

The geology of the northeastern part of the Presque Isle quadrangle also has been remapped by the writer and is in general agreement with the earlier mapping of White (1943, pl. 24) for this area; he also did not recognize the Carys Mills Formation (formerly ribbon limestone member of the Aroostook Limestone) here. The western boundary of the Carys Mills Formation in the Caribou, Stockholm, and Van Buren quadrangles was originally mapped by Douglas Smith and R. S. Naylor of the California Institute of Technology. Delineation of this boundry was subsequently modified slightly by Dr. Ely Mencher and his students of the Massachusetts Institute of Technology. The distribution of the Carys Mills Formation in different parts of the Fort Fairfield quadrangle has been independently mapped by the writer and by Mencher and David C. Roy of the Massachusetts Institute of Technology.

\section{ACKNOWLEDGMENTS}

Since 1956, parts of northeastern Maine have been mapped in considerable detail. In the course of this work, numerous fossil localities were discovered that enabled the dating of heretofore poorly known rocks and a closer dating of stratigraphic formations in general. The credit for the discovery of fossil locations other than those found by the writer is cited in the tables or text of this report. However, special recognition is due Mr. William H. Forbes of Washburn, Maine, who discovered several critical fossil localities and freely made and gave collections from these localities to the geologists working in northern Maine.

The discovery of fossils that can be closely zoned in the geologic section in many critical lithologies has enabled a better understanding of facies relationships to be deduced between lithologically dissimilar formations. Such paleontologic information came from many specialists who kindly examined and dated the fossil collections of the writer and other geologists from this general region. Without such paleontologic information, the various facies interpretations discussed in this report could not have been made. The writer is particularly indebted 
to Dr. W. B. N. Berry of the University of California at Berkeley who identified and dated the graptolites, which, because of their presence in several contrasting lithologies, proved critical in reaching the conclusions presented here. A. J. Boucot and R. B. Neuman identified the brachiopods listed in this report, and through their interest and painstaking efforts obtained useful information from the generally poorly preserved and highly deformed fossils that were submitted to them for study. L. M. Cumming of the Geological Survey of Canada kindly made available his paleontologic determinations from several localities in New Brunswick, discovered either by himself or his colleagues on the Geological Survey of Canada.

The writer is also indebted to the various geologists of the Geological Survey of Canada and the New Brunswick Department of Land and Mines for inviting and encouraging his reconnaissance geologic mapping of contiguous areas in New Brunswick.

Assistance during fieldwork was given successively by William Barton (1956), Stepan Peniuk (1957), Richard Mauger (1958), W. W. Williams (1959), Henry Hanson III (1960-62), Allen Barrows (196162), J. S. Derr (1962-63), Douglas Smith (1963), J. R. Griffin (196364), and Andrew MacCormack (1965).

\section{GENERAL GEOLOGIC SETTING}

The part of northeastern Maine and contiguous New Brunswick described in this report (fig. 1) consists of a broad valley or lowland with gently rolling hills; its irregular margins are bounded by uplands of slightly higher altitude. This topography closely reflects the bedrock geology of the region, as the uplands marginal to the lowland are underlain by slate, sandstone, quartzite, conglomerate, and volcanic rocks. In contrast, the lowland is underlain by the chiefly limy core rocks of the Aroostook-Matapedia anticlinorium that are less resistant to erosion than the upland rocks. The rolling hills of the lowland commonly are supported by slate or siltstone or other relatively resistant rocks. Mars Hill (pl. 1), composed of conglomerate, quartzite, and siltstone, forms a conspicuous monadnock in the lowland province.

Glacial drift covers much of the region. In places, it forms eskers, kames, kame fields, outwash plains, valley trains, and other related ice-contact and glaciofluvial features of continental glaciation (Pavlides, 1965; Lee, 1962). Much of the drift contains large amounts of locally derived bedrock material. Hence, the more fertile land, which has been cleared for farming, lies mostly within the lowland that is underlain by limy rocks (Pavlides, 1965, p. 5). 


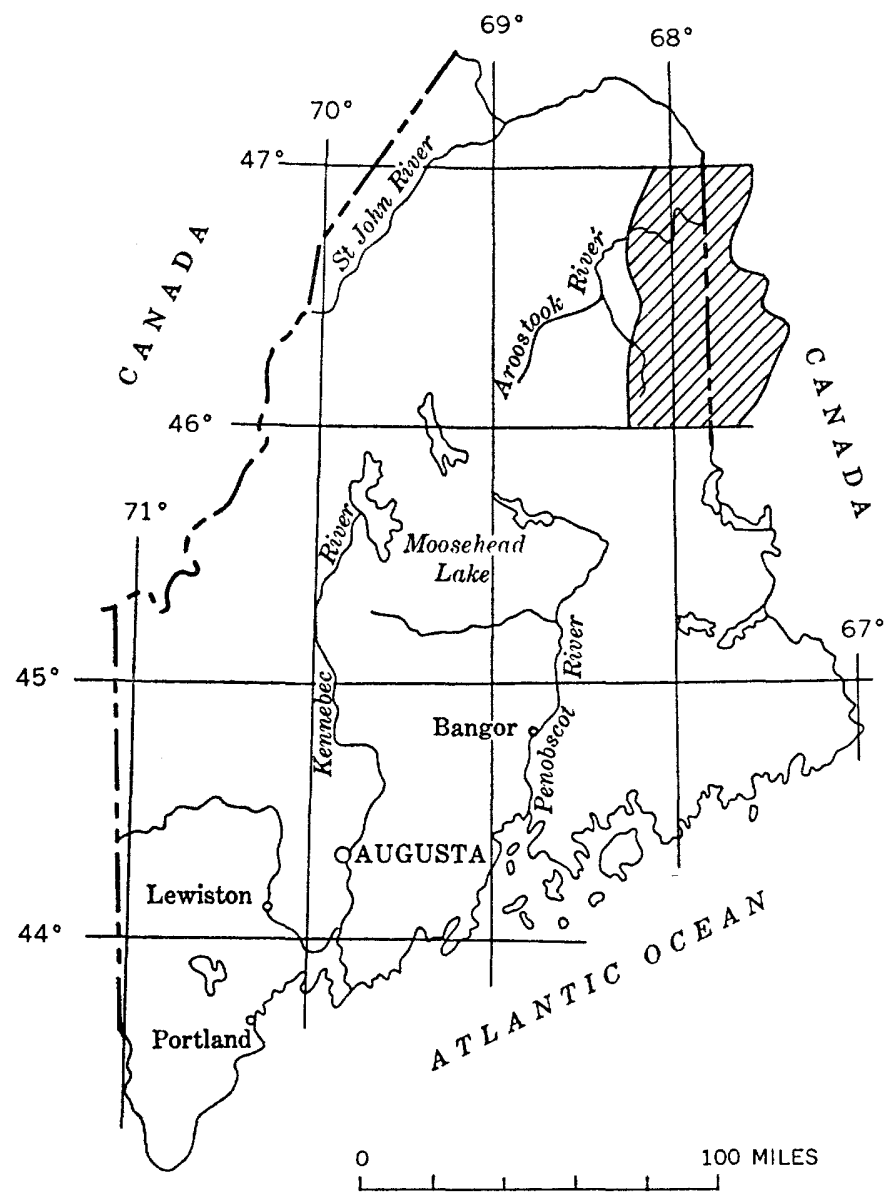

Figure 1.-Index map of Maine and adjoining Canada. Area of investigation is shaded.

The core rocks of the Aroostook-Matapedia anticlinorium are chiefly steeply dipping, closely folded sedimentary rocks generally cut by a well formed slaty fracture cleavage (Pavlides, 1965, p. 52-53). Similar tectonic features characterized the less competent rocks at the margins of the Aroostook-Matapedia anticlinorium. Competent rocks in parts of the areas peripheral to the anticlinorium, however, form more open folds with beds having moderate to low dips that commonly are not cleaved. The rocks within and along the flanks of the anticlinorium at its south end have been locally intruded by postkinematic granitic plutons of Devonian age. A great variety of dikes that in most places have thermally metamorphosed the rocks they have intruded also are locally abundant. Rocks in the southern part of the region, up to about 
the latitude of Presque Isle, are in the chlorite grade of regional metamorphism. In general, north of this latitude, the rocks are free of regional metamorphism except for the slaty cleavage that cuts many of them.

\section{STRATIGRAPHY}

The core rocks of the Aroostook-Matapedia anticlinorium in northern Maine and adjoining New Brunswick are almost all of Ordovician and Silurian age. The most widespread and characteristic sedimentary rocks in the core belong to the Carys Mills Formation, which was named and described earlier (Pavlides, 1966b, p. A52-A57). This formation includes rocks previously assigned to the ribbon rock member of the Meduxnekeag Formation and to the ribbon limestone member of the Aroostook Limestone. For convenience, and to avoid repetition, these rocks will henceforth be described as the Carys Mills Formation, with the understanding that the reports referred to actually describe them as members of the Meduxnekeag Formation and Aroostook Limestone. Tables 1 and 2 indicate the revisions introduced into the Meduxnekeag Formation and Aroostook Limestone (abandoned name), respectively, by the writer (1966b) and that will be henceforth used in this report.

TABLE 1.-Comparison of the Meduxnekeag Formation of former usage with the Meduxnekeag Group

\begin{tabular}{|c|c|c|c|c|c|}
\hline \multicolumn{3}{|c|}{ Pavlides $(1962,1965)$} & \multicolumn{3}{|c|}{ Pavlides (1966b) } \\
\hline \multirow{3}{*}{$\begin{array}{l}z \\
\Xi \\
0 \\
0 \\
0 \\
0 \\
0 \\
0 \\
0\end{array}$} & \multirow{3}{*}{ 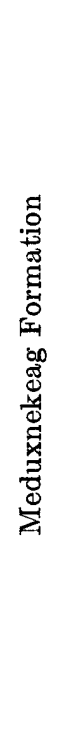 } & Slate member & 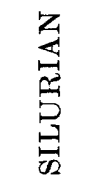 & \multirow{3}{*}{ 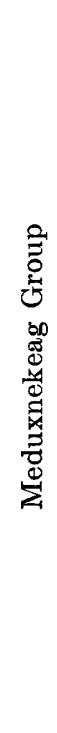 } & $\begin{array}{c}\text { Burnt Brook } \\
\text { Formation }\end{array}$ \\
\hline & & Ribbon rock member & 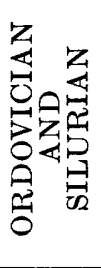 & & $\begin{array}{l}\text { Carys Mills } \\
\text { Formation }\end{array}$ \\
\hline & & $\begin{array}{l}\text { Slate and graywacke } \\
\text { member }\end{array}$ & 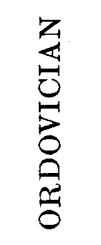 & & $\begin{array}{l}\text { Chandler Ridge } \\
\text { Formation }\end{array}$ \\
\hline
\end{tabular}


TARLe 2.-Summary of revisions of superposition, chronology, and nomenclature in the Aroostook Limestone of former usage in northern Maine

\begin{tabular}{|c|c|c|c|c|c|c|c|}
\hline \multicolumn{3}{|c|}{ White (1943) } & \multicolumn{3}{|c|}{ Boucot and others (1964) } & \multicolumn{2}{|c|}{ Pavlides (1966 b) } \\
\hline \multirow{4}{*}{ 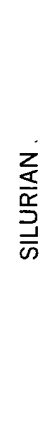 } & \multicolumn{2}{|r|}{$\begin{array}{l}\text { Shale and slate unit } \\
\text { (lower member) }\end{array}$} & \multirow{4}{*}{ 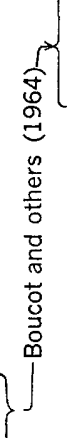 } & \multirow{2}{*}{ 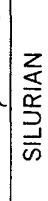 } & $\begin{array}{l}\text { Perham Formation } \\
\text { (lower member) }\end{array}$ & \multirow{2}{*}{ 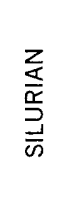 } & $\begin{array}{l}\text { Perham Formation } \\
\text { (lower member) }\end{array}$ \\
\hline & \multirow{3}{*}{ 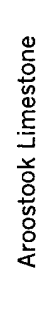 } & $\begin{array}{l}\text { Upper member } \\
\text { nubbly limestone }\end{array}$ & & & Unnamed limestone & & $\begin{array}{l}\text { Spragueville } \\
\text { Formation }\end{array}$ \\
\hline & & $\begin{array}{l}\text { Middle member } \\
\text { ribbon limestone }\end{array}$ & & \begin{tabular}{|l|}
$z$ \\
$\frac{x}{0}$ \\
0 \\
$z$ \\
0 \\
0 \\
0 \\
0 \\
\end{tabular} & $\begin{array}{l}\text { Meduxnekeag } \\
\text { Formation } \\
\text { (ribbon rock } \\
\text { member) }\end{array}$ & 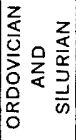 & $\begin{array}{l}\text { Carys Mills } \\
\text { Formation }\end{array}$ \\
\hline & & $\begin{array}{l}\text { Lower member slate } \\
\text { and calcareous slate }\end{array}$ & & & & & \\
\hline
\end{tabular}

\section{MEDUXNEKEAG GROUP}

The Meduxnekeag Group was originally mapped in the northwest corner of the Bridgewater quadrangle, Maine (Pavlides, 1962, p. 9-12, and pl.1). Since then, the writer has mapped all the Bridgewater quadrangle (Pavlides, 1965) where the Meduxnekeag Group, particularly the Carys Mills Formation, is widely exposed, and has also mapped rocks belonging to the Carys Mills Formation in the Houlton and Smyrna Mills quadrangles, Maine (Pavlides and Canney, 1964; Pavlides and Berry, 1966 ; Pavlides, unpub. data), and the Mars Hill quadrangle, Maine (Pavlides, unpub. data).

The Meduxnekeag Group, as now defined (Pavlides, 1966b, p A52A55), consists of the Chandler Ridge, Carys Mills, and Burnt Brook Formations. The thicknesses of these formations were determined in the Bridgewater quadrangle where they were originally described as members of the Meduxnekeag Formation (Pavlides, 1965, table 1). It should be emphasized that these thicknesses are to be considered only as orders of magnitude, chiefly because of the degree of deformation the rocks have undergone and because the thicknesses are estimates based on measurements made from geologic cross sections constructed at various places in the Bridgewater quadrangle. These thickness estimates are directly dependent upon the interpretation of the deformation pattern and geometry of the folds used in the cross sections.

\section{CHANDLER RIDGE FORMATION}

The slate and graywacke member of the Meduxnekeag Formation (Pavlides, 1962, p. 10-11; Pavlides, 1965, p. 7-14) is now named the 
Chandler Ridge Formation of the Meduxnekeag Group after Chandler Ridge in the Bridgewater quadrangle (see fig. 1), where the formation is best exposed (Pavlides, 1966b, p. A54-A55).

Lithology.-Slate and graywacke and lesser amounts of siltstone and quartzite interbedded in various proportions form the Chandler Ridge Formation. The slate is dark gray and gray green; the graywacke is gray or green and consists of quartzose, lithic, and feldspathic varieties (Pavlides, 1965, p. 9-14). Beds of slate and of graywacke range from a few inches to as much as 50 feet in thickness. The siltstone and quartzite beds are generally a few inches to a few feet thick.

Thickness.-The Chandler Ridge Formation is believed to be as much as 5,000 feet thick in the northwestern part of the Bridgewater quadrangle. Its restriction to this quadrangle suggests that it is a lenticular deposit that thins and wedges out rapidly away from its outcrop area.

Age.-Fossils have not been found in the Chandler Ridge Formation and its stratigraphic relationship to the Carys Mills Formation is not precisely established. Sparse structural and sedimentologic features suggest it underlies the Carys Mills (Pavlides, 1965, p. 8). Its lower contact is not exposed. Because the age of the overlying Carys Mills ranges from Middle Ordovician to Early Silurian, part of the Chandler Ridge is probably Middle Ordovician or older. However, because the Carys Mills Formation is thin on the west side of the Chandler Ridge Formation in the Bridgewater quadrangle, and as the Chandler Ridge is thought to be lenticular, part of it may be younger than Middle Ordovician. Therefore, it is provisionally considered to be of Ordovician (?) age.

\section{CARYS MILLS FORMATION}

The ribbon rock member of the Meduxnekeag Formation of former usage (Pavlides, 1962, 1965 ; Pavlides and Berry, 1965; Pavlides and others, 1964 ; Pavlides and Canney, 1964; and Boucot and others, 1964) has been named the Carys Mills Formation for the community of Carys Mills in the Houlton quadrangle, where rocks typical of this formation are exposed.

Lithology.-The Carys Mills Formation is a widespread limy unit. Although it contains many lithologic varieties (Pavlides, 1965), it is nonetheless readily recognizable in a continuous and wide belt in northeastern Maine and northwestern New Brunswick. Among its distinctive features are the gray-blue to blue color of the limestone and calcareous siltstone beds, which are the dominant rock types of the formation, the distinctive buff to 'tan weathering of the ankeritic beds, and the gray-white weathering of calcic layers. Very fine grained muscovite is common along bedding planes of most silty limestone beds. 
Such limy beds are commonly interlayered with each other or with slate. Because slate is more resistant, it normally stands out in relief as small ribs between the more deeply eroded ankeritic or calcic carbonate layers. Intrastratal contortion and convolute layering are also very characteristic of the silty limestone and calcareous siltstone layers (Pavlides, 1965, p. 16 and fig. 4). Sole markings of various types and small-scale load casts and flute markings are also present locally but are often difficut to see because, in most places, a well formed transverse regional slaty cleavage obliterates such sedimentary features. At some places, poorly formed graded bedding is also present; it is characterized by a gradual change from a calcareous siltstone or silty limestone at the base of the bed upwards into a pelitic zone that is separated by a sharp contact from the overlying calcareous silty bed. At two places where shelly faunas occur (loc. $19 \mathrm{~A}$ and 31 of pl. 1), the fossils are broken and suggest transportation by currents.

At locality 31 a lens of dark-gray coarse-grained limestone contains only small brachiopods. The fossils at locality 19A occur in thin (onehalf inch or less thick) layers of impure calcareous arenite containing disarticulated pelmatazoan debris and lesser amounts of fragments of bryozoans, ostracodes and brachiopods. All fossiliferous debris is in about the same size range and occurs with quartz grains and slate chips of comparable size.

Many of the above sedimentologic features are characteristic of deposits laid down by turbidity currents, such as flysch deposits (Dzulynski and Walton, 1965, p. 37-187) ; the Carys Mills Formation may in part be a variety of calcareous flysch. Also characteristic of the Carys Mills are the generally abundant calcite-filled veinlets and gash fractures. These are probably of tectonic origin; the calcite locally derived from the limy layers of the formation was deposited in fractures formed through deformation. In parts of the region, lenses of slate or slate and graywacke form mappable units within the limy rocks of the Carys Mills. These are particularly abundant in the Bridgewater quadrangle, where they have been mapped as lenses whose position within the Carys Mills is not known (Pavlides, 1965). Some of these lenses actually may be stratigraphically above the Carys Mills and temporal equivalents of the lower part of the Smyrna Mills Formation which crops out further south (Pavlides and Berry, 1966). Some of these lenses have been reexamined and are so regarded in this report (see pl. 1) although they were assigned earlier entirely as lenticular units within the Carys Mills (Pavlides, 1965). Beds of graywacke, normally not much thicker than 2 feet, are present as interbeds within carbonate rocks at a few places in the report area. Thicker 
lenses of graywacke and fine-grained conglomerate are present in the north-central part of the Houlton quadrangle.

The petrography of the various rock types that compose the Carys Mills Formation in the Bridgewater quadrangle has been described elsewhere (Pavlides, 1965) and is considered to be representative of the Carys Mills Formation throughout its outcrop belt.

Thickness.-The thickness of the Carys Mills Formation is difficult to estimate, not only for the reasons stated earlier but also because the basal part of the formation is not exposed in most of the outcrop belt of the Carys Mills. Where it rests on older rocks, such as the Chandler Ridge Formation in the northwestern part of the Bridgewater quadrangle, it apparently thins to the west; its minimum thickness in the northwestern part of the quadrangle has been estimated to be about 1,500 feet. At this place it occurs as a thin band separating the younger Burnt Brook and the older Chandler Ridge Formation. Elsewhere in the Bridgewater quadrangle, it is estimated to be at least 12,000 feet thick. White (1943, p. 129) estimated that the entire Aroostook Limestone in the Presque Isle area is about 18,000 feet thick; his "middle member ribbon limestone," now classed as the Carys Mills Formation (see table 2), probably forms at least half or about 9,000 feet of the section in the Presque Isle area. Boucot and others (1964, p. 25) made no attempt to estimate the thickness of these rocks in the Presque Isle quadrangle, aside from saying that the unit was probably thick. The 12,000 feet estimated for the Carys Mills in the Bridgewater quadrangle might eventually prove to be excessive, but it nonetheless is an approximate order of magnitude for this unit, attested to, in part, by the occurrence of the unit through a broad belt within which older rocks have not generally been recognized.

Age.-The Carys Mills Formation is of Middle Ordovician to Early Silurian age. Table 3 contains a list of the faunas from the various fossil localities that occur within the formation. Earlier, the Carys Mills Formation was considered by the writer to be of Ordovician age, on the basis of the paleontologic information then available (Pavlides, 1962), and it has been so assigned in subsequent reports (Pavlides, 1965; Pavlides and others, 1964; Pavlides and Canney, 1964; Boucot and others, 1964). The discovery of Early Silurian graptolites near Timony Lake and near Washburn, Maine (loc. 28 and 5 of table 3, see also pl. 1), established the fact that the Carys Mills ranges into the Early Silurian (Pavlides and Berry, 1966). Rocks now considered also to belong to the Carys Mills had earlier yielded Rastrites near Lindsay, New Brunswick (loc. 25, pl. 1).

The most useful fossils for fixing the upper limit of the range of the Carys Mills Formation into the Silurian were found near Timony 
Lake about 300 feet below the top of the formation (loc. 28 of table 3 ); these, like those found in the Smyrna Mills Formation about 50 feet above the top of the Carys Mills Formation (loc. 27 of pl. 1; see also Pavlides and Berry, 1966, p. B55) represent graptolite zone 19 of Early Silurian Llandovery age. The contact between the Carys Mills and Smyrna Mills Formations is gradational and is characterized by an interval about 300 feet thick consisting of green and gray siltstone and slate irregularly interlayered by gray-blue limestone and calcareous siltstone beds characteristic of the Carys Mills Formation. This gradational zone has been placed at the top of the Carys Mills Formation (Pavlides and Berry, 1966, p. B53). Thus, paleontologic data at hand show that the Carys Mills apparently ranges from Caradoc (Barneveld) in the Ordovician up to the interval $\mathrm{A}_{4}-\mathrm{B}_{1}$ of the middle Llandovery in the Lower Silurian.

\section{BURNT BROOK FORMATION}

The Burnt Brook Formation underlies a small area mostly within the west-central part of the Bridgewater quadrangle (see pl. 1). Here it overlies the thinnest part of the Carys Mills Formation known in the region. Originally, the Burnt Brook was designated the slate member of the Meduxnekeag Formation (Pavlides, 1962, p. 12; 1965, p. 2021), but it has since been named the Burnt Brook Formation after Burnt Brook, along and near which it is exposed (Pavlides, 1966b, p. A55).

Lithology.-The Burnt Brook consists chiefly of green noncalcareous and gray calcareous slate. Sparse interbeds of thin gray-blue limestone similar to the limestone beds of the Carys Mills Formation are also present at a few places.

Thickness.-The Burnt Brook Formation is about 5,000 feet thick, the thickness assigned to it when it was originally described as a member of the Meduxnekeag Formation (Pavlides, 1965, p. 20).

Age.-The Burnt Brook Formation is assigned a Silurian(?) age. No fossils have been found in it, and this age assignment is inferred from the fact that it conformably overlies the Carys Mills Formation. The Carys Mills where overlain by the Burnt Brook is thin, however, probably because of stratigraphic wedging out toward the west (Pavlides, 1965, p. 20). Furthermore, the precise age of the Carys Mills where it underlies the Burnt Brook is not known; the possibility exists, therefore, that the Carys Mills may here be of Ordovician rather than Silurian age and hence the overlying lenticular Burnt Brook may also be of Ordovician age. For purposes of this report, however, the Burnt Brook is provisionally assigned a Silurian(?) age. It may be partly coeval with the Smyrna Mills Formation, the Maple Mountain Formation, and the lower member of the Perham Formation. 


\section{TABLE 3.-Fossil localities within the Carys Mills Formation}

[All graptolites identified by W. B. N. Berry of the University of California at Berkeley, except for Rastrites of loc. 25, which was identified by L. M. Cumming of the Geological Survey of Canada; brachiopods of loc. 31, identified by A. J. Boucot and R. B. Neuman of the U.S. Geological Survey; Tomaculum of loc. 19 identified by Walter Häntzschel of the Geologisches Staatsinstitut, Hamburg]

\begin{tabular}{|c|c|c|c|c|c|c|c|c|c|c|}
\hline Locality numbers. - & 1 & 5 & 6 & 19 & 25 & 31 & 30 & 32 & 29 & 28 \\
\hline U.S. Geol. Survey colln..... & CO 4132 & & $\ldots .$. & CO 4133 & $\cdots$ & CO 5472 & CO 5470 & CO 5471 & CO 5469 & SD 7451 \\
\hline $\begin{array}{l}\text { Amplexograptus sp.... } \\
\text { A. cf. } A \text {. perexcavatus } \\
\quad \text { (Lapworth) }\end{array}$ & $\begin{array}{l}\mathrm{X} \\
\mathrm{X}\end{array}$ & & & & & & $?$ & & & \\
\hline $\begin{array}{l}\text { Climacograptus } \mathrm{sp}_{-} \\
\text {C. cf. tupicalis mut, posterus }\end{array}$ & & & & $-\ldots$ & & & -- & & & $\mathrm{X}$ \\
\hline $\begin{array}{l}\text { C. cf. typicalis mut. posterus } \\
\text { Ruedemann }\end{array}$ & $\mathrm{X}$ & & & & & & & & & \\
\hline $\begin{array}{l}C . \text { sp. (of the C. scalaris } \\
\text { type) }\end{array}$ & & & & & $\mathrm{X}$ & & & & & \\
\hline $\begin{array}{l}\text { C. sp. (of the C. rectan- } \\
\text { gularis type) }\end{array}$ & & & & & $\mathrm{X}$ & & & & & \\
\hline $\begin{array}{l}\text { C. } \text { ef. scalaris cf. var. } \\
\text { normalis Lapworth.... }\end{array}$ & & & & & & & & & & $\mathrm{X}$ \\
\hline Diplograptus spp. & $\underset{\mathrm{Y}}{\mathrm{X}}$ & & & -- & $\ldots$ & $\ldots$ & $\cdots$ & & & $-\cdots$ \\
\hline $\begin{array}{l}\text { D. cf. D. multidens } \\
\text { Monograptus cyphus }\end{array}$ & $\mathrm{X}$ & & $\ldots$ & $-\cdots$ & $-\cdots$ & $\cdots-\cdots$ & 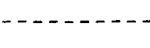 & $\ldots$ & $\cdots+\cdots$ & 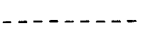 \\
\hline $\begin{array}{l}\text { Monograptus cyphus } \\
\text { M. revoltus Kurck }\end{array}$ & $\cdots$ & $\mathrm{X}$ & 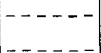 & $\ldots$. & $\ldots$ & $-\ldots-\ldots$ & $-\cdots--1$ & 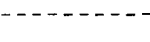 & $\ldots . .$. & -- \\
\hline $\begin{array}{l}M . \text { revoltus Kurck. } \\
M . \text { revoltus ef. var. aus- }\end{array}$ & & $\cdots$ & $\cdots-1$ & ------ & -...- & - & -. & - & $-\cdots-$ & $\mathrm{X}$ \\
\hline M. revoltus ef. var. aus- & & & & & & & & & & $\mathrm{X}$ \\
\hline M.triangulatus (Harknes & & & & & & & & & & $\mathrm{X}$ \\
\hline
\end{tabular}


Orthograptus aff. O. trun\& catus (Lapworth) $\ldots . . . . . . \mathrm{X}$

medius (Elles and Wood) _.. $\mathrm{X}$

o. truncatus var. socialis

(Lapworth)

Rastrites sp

¿ Rhaphidograptus sp. (Elles and Wood)

Climacograptid or glyptograptid.

Dendroid graptolite.

Orthograptid of the $O$.

truncatus type......-

Orthograptid of the $O$.

calcaratus type.

Zygospira sp.

Leptellid.

Tomaculum ef. T. problematicum Groom.

$\mid$\begin{tabular}{|l}
$\mathrm{X}$ \\
$\mathrm{X}$ \\
$\mathrm{X}$ \\
$\mathrm{X}$ \\
\hdashline \\
\hdashline
\end{tabular}
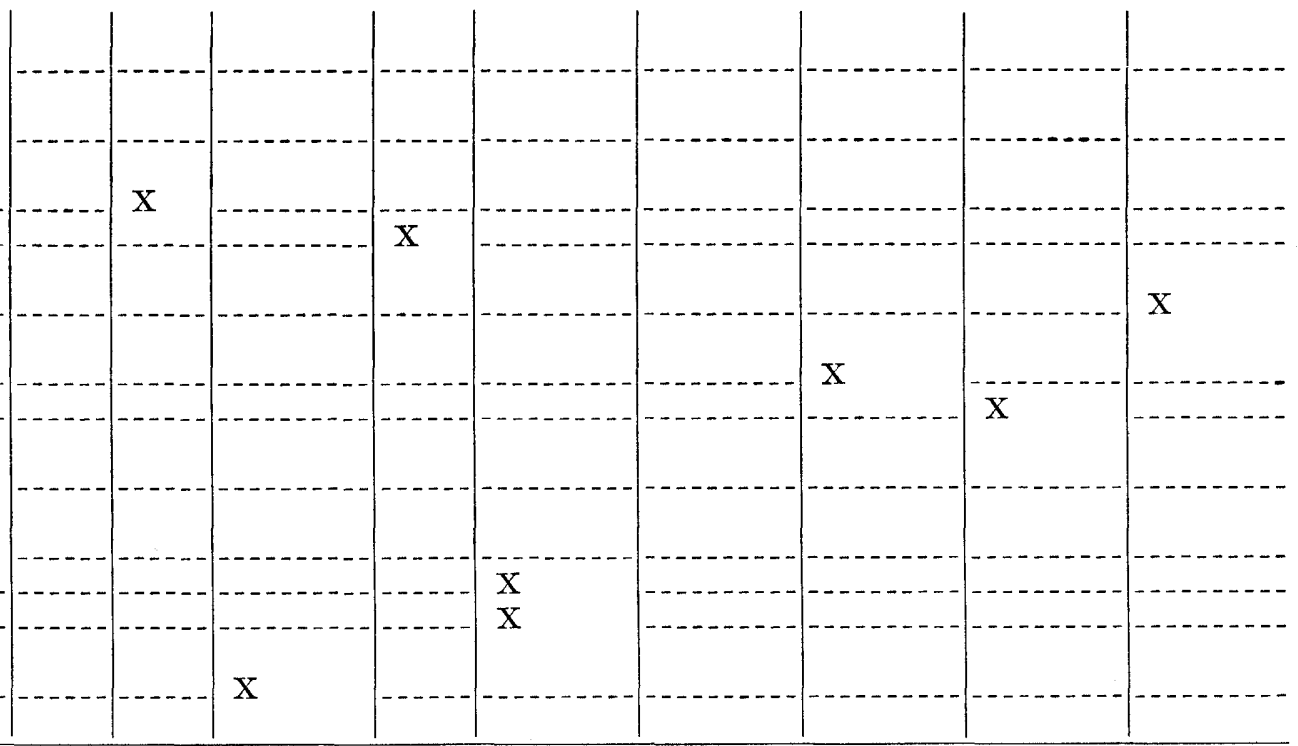

Age of collections

Locality 1. Middle Ordovician (Trenton)

5. Early Silurian (British graptolite zone 18)

6. Late Ordovician (probably British graptolite zone 15)

19. Ordovician

25. Early Silurian (British graptolite zone 19)
31. Middle or Late Ordovician

30. Probable Ordovician

32. Late Ordovician or Early Silurian (probably late Ordovician)

29. Ordovician or Silurian

28. Early Silurian (British graptolite zone 19) 


\section{REDEFINED FORMATIONS}

\section{AROOSTOOK LIMESTONE (ABANDONED NAME)}

The Aroostook Limestone, as originally named by Williams and Gregory $(1900$, p. 44, 141), referred to the belt of rocks exposed along the Aroostook River from Wade Township in Maine to the confluence of the Aroostook and St. John Rivers in New Brunswick. These rocks were believed to be of Silurian age (Williams and Gregory, 1900, p. 44). However, this belt of rocks contains several distinct formations of Ordovician and Silurian age, and the Aroostook Limestone is not a useful stratigraphic term as originally defined. Twenhofel (1941, p. 167) recognized that the Aroostook Limestone of Williams' and Gregory's usage contained sedimentary rock types other than limestone and used the term "Aroostook Formation" to describe these rocks. He also questioned the Silurian age assigned these rocks and suggested that they more probably were of Ordovician age (Twenhofel, 1941, p. 168-169). Twenhofel suggested an Ordovician age for these rocks because they were more highly deformed than the thendated Silurian rocks of the region, hence had undergone an earlier deformation during the Taconic disturbance, and so were pre-Silurian in age. Although his reasons for this age assignment are no longer valid, he nonetheless was the first to recognize the lithologic similarity of the Aroostook Formation (of his usage) and its correlation "with some part of the Matapedia Division (Ordovician) of Crickmay (1932) or the Whitehead (Cape Blanc) formation of Schuchert and Cooper (1930)."

White (1943, p. 128-129) retained the term "Aroostook Limestone" in the mapping he and Preston E. Cloud, Jr., carried out in the Presque Isle area (White, 1943, pl. 24). However, recognizing the lithologic complexities of this unit, White and Cloud divided the Aroostook Limestone into three units, which, in ascending order, were: (1) slate and calcareous slate, (2) middle member ribbon limestone, and (3) upper member, nubbly limestone (see table 2). This usage was also followed by Miller (1947). White and Cloud considered the "Aroostook Limestone" of their usage to be about 18,000 feet thick and to be of Middle Silurian age (White, 1943, p. 129). The writer correlated the middle, or ribbon limestone, member of the Aroostook Limestone of White and Cloud's usage with the ribbon rock member of the Meduxnekeag Formation which was by then believed to be of Ordovician age (Pavlides, 1962, p. 21-23). The writer's original stratigraphic usage for this unit was also used by Boucot and others (1964, p. 23-24) in the Presque Isle quadrangle of Maine. Since that time, the age of the ribbon rock member of the Meduxnekeag Formation (Carys Mills Formation of this report) has been revised as rang- 
ing from Middle Ordovician to Early Silurian in age (Pavlides and Berry, 1966). In addition, the studies of Boucot and others (1964) in the Presque Isle and nearby quadrangles of northern Maine show that the tripartite subdivision of White and Cloud for the Aroostook Limestone was, in part, inverted, and that the three members of this unit have a wider range in age than Middle Silurian, as originally assigned them by White and Cloud (see table 2 ). The lower, slate and gray calcareous slate, member of the Aroostook Limestone was placed by Boucot and others (1964) above the upper, nubbly limestone member of White and Cloud's usage and assigned to the lower part of the Perham Formation (table 2). This revision was anticipated by White, who recognized that, within limits of the information available to him when he prepared his report, he might have erroneously separated different rocks of the same unit, namely, "that the rocks mapped as the lower member of the Aroostook Limestone actually are equivalent to the shales above the Aroostook" (White, 1943, p. 128).

Because of the different definitions and usages accorded the Aroostook Limestone or its members by different geologists, and because the superpositional order of one of its three members is inverted, the name Aroostook Limestone of the usage of White (1943) has been abandoned (Pavlides, 1966b). Table 2 summarizes the revisions in the stratigraphy, age, and nomenclature of the Aroostook Limestone of White's usage. Rock units previously assigned as members of the Aroostook Limestone of White's usage are now assigned, in ascending order, to the Carys Mills Formation, the Spragueville Formation, and the lower member of the Perham Formation. The former middle or ribbon limestone member of the Aroostook Limestone is now known to be coextensive with the former ribbon rock of the Meduxnekeag Formation; therefore, both these units have been assigned to the Carys Mills Formation.

\section{SPRAGUEVILLE FORMATION}

The Spragueville Formation was named for the community of Spragueville, Maine (pl. 1), near which rocks belonging to this formation are exposed (Pavlides, 1966b, p. A55-A57). White was the first to recognize the Spragueville as a mappable unit and referred to it by this name informally in his field notes. However, in his report, White (1943) made this unit the upper, nubbly limestone member of the Aroostook Limestone of his usage (table 2 ) and considered it to be of Middle Silurian age. Boucot and others (1964, p. 26-29) also recognized this unit in the Presque Isle quadrangle and referred to it as an "Unnamed Silurian limestone" (see table 2 ) of $\mathrm{C}_{3}-\mathrm{C}_{5}$ late Llandovery (approximately early Clinton) age. However, Boucot and others (1964, pl. 1) did not distinguish these rocks from the limy rocks of the Carys Mills 
Formation in the northeastern part of the Presque Isle quadrangle and have included a large area of the Spragueville in the Carys Mills in this region. In remapping this particular area, the writer agrees, in general, with the earlier mapping of White who also had mapped the rocks here as "Spragueville." However, the writer believes the Spragueville is, in part, in fault contact with the other Paleozoic rocks to the west (see pl. 1). Breccia occurs in the Spragueville Formation in a core logged by the writer from a drill hole along this fault. This drill core was generously made available to the writer for examination by the Soil Conservation Service of the U.S. Department of Agriculture.

Lithology.-White (1943, p. 129) briefly described the rocks assigned herein to the Spragueville simply as "gray, nubbly argillaceous limestone." Boucot and others (1964, p. 26-29), who had placed these rocks of the Spragueville Formation in their "unnamed Silurian limestone," described this formation as consisting chiefly of

\begin{abstract}
“*** silty gray limestone in beds $1 / 2$ inch to 2 inches thick. The bedding surfaces are generally rough and are either plane or gently warped. Fine-scale internal banding is common within the limestone beds. These bands are normally parallel to the bedding but are gently convolute in a few places. Rounded nodules about one-half inch in diameter are present in some of the beds, and this apparently caused White $(1943$, pl. 24$)$ to characterize the unit as "nubbly" limestone. Although the beds of limestone are commonly separated by very thin argillaceous layers, the interbeds of shale or slate that are prominent in the ribbon rock [member of the Meduxnekeag Formation] are generally absent in the unnamed Silurian limestone."
\end{abstract}

This description is generally applicable to the rocks of the Spragueville Formation in the Presque Isle area. It should be added that a paleolive-green color that may, in part, be related to pervasive weathering is quite common to these rocks. Also, there seems to be a wide gradation from silty limestone to limy siltstone in rocks that have been described as "nubbly" limestone.

Thickness.-Boucot and others (1964, p. 27) estimated the thickness af their unnamed Silurian limestone, or Spragueville Formation of this report, to be about 4,000 feet. Because of the absence of sections usable for measuring the thickness of the Spragueville, it is necessary to estimate its thickness from selected cross sections. Such an estimate is governed, in part, by the fold geometry as well as the number of folds that can be recognized by mapping. Thus, the thickness estimate for the Spragueville, as for many of the formations of northern Maine, represents an order of magnitude rather than a precise thickness value.

In the Presque Isle region, the Spragueville is estimated to be about 3,000 feet thick and apparently wedges out to the south (see pl. 1). 
Age.-The Spragueville Formation seems to span the interval of about $A_{4}-B_{1}$ to $C_{3}-C_{5}$ of the Llandovery. The older age is based on graptolites at locality 2 of plate 1 that include:

Climacograptus cf. C. scalaris var. miserabilis Elles and Wood

Monograptus communis (Lapworth)

Rastrites sp.cf. R. approximatus approximatus (Perner)

This assemblage is "of the age of Elles and Wood's Zone 19 or 20, which form the older part of the Middle Llandovery" (W. B. N. Berry, written commun., Nov. 2, 1964). A sample from a layer containing fragmental fossiliferous debris (loc. 3 of pl. 1) was collected by the writer near the above graptolite locality, but it contained only fragments of indeterminate brachiopods (A. J. Boucot, written commun., Nov. 10, 1964). A climacograptid found by W. H. Forbes at locality 4 of plate 1 could not be specifically identified by W. B. N. Berry, but is not inconsistent with the Early Silurian age of locality 2.

Several fossil localities occur in the Spragueville Formation in the Presque Isle area, but only the collection from locality 11 (pl. 1) is useful in dating the Spragueville. This locality (U.S. Geol. Surrey 6816-SD) is discussed by Boucot and others (1964, p. 28-29). The critical fossils for dating the collection are those identified by Jean M. Berdan of the U.S. Geological Survey and consist of the following ostracodes:

Apatobolbina sp.,

Bolbineossia sp.,

Zygobolba inflata Ulrich and Bassler

According to Berdan, "this collection is presumably equivalent in age to the lower part of the type Clinton of New York, the lower Rose Hill of Maryland, the lower Jupiter River of Anticosti and may be slightly older than the Schoolcraft Dolomite of Michigan" (Boucot and others, 1964, p. 28).

In addition, Boucot identified the following brachiopods from this locality:

Atrypa "reticularis,"

Coelospria cf. C. saffordi,

Dalejina sp.,

Dicoelosia sp.,

Glassia sp.,

Howellella sp.,

Leptaena rhomboidalis, Mesopholidostrophia sp.,

Nucleospira sp.,

Plectodonta sp.,

Resserella sp., 
Orthotetacid indet.,

Rhynchonellid indet.

This brachiopod assemblage apparently has a wider range $\left(\mathrm{C}_{3}\right.$ or younger of the late Llandovery to Ludlow) than the ostracodes, which indicate a $\mathrm{C}_{3}-\mathrm{C}_{5}$ span of the Llandovery; the ostracode span is the age assigned to this locality (Boucot and others, 1964, p. 29).

The additional paleontologic information now available from the Fort Fairfield and Presque Isle areas indicates that the Spragueville Formation apparently is in the span of about $\mathbf{A}_{1}-\mathbf{B}_{4}$ (middle) to $\mathrm{C}_{3}-\mathrm{C}_{5}$ (late) Llandovery. However, in the vicinity of Spragueville, where the lower part of the Perham Formation is absent, the Spragueville Formation directly underlies the upper part of the Perham (pl. 1), which here contains graptolites of early Ludlow age (Boucot and others, 1964, p. 38-39). Thus, the Spragueville here may locally be as young as pre-early Ludlow. The age of the Spragueville, as determined from fossils, therefore, is middle and late Llandovery, and on stratigraphic considerations it may range through the Wenlock.

\section{PERHAM FORMATION}

The Perham Formation was named and described by Boucot and others (1964, p. 33-40), who divided it into an upper and lower member. The lower member of the Perham in large part contains what was the lower member of the Aroostook Limestone of White's usage and the lower part of the unnamed unit that White considered to overlie the Aroostook Limestone (see table 2). The upper member of the Perham Formation is equivalent to the limestones and shales included as the upper member of White's unnamed Silurian unit above his Aroostook Limestone (1943, p. 129).

\section{LOWER MEMBER OF THE PERHAM FORMATION}

This report follows, in general, the definition and usage for the lower member of the Perham Formation, as given by Boucot and others (1964, p. 34-35). However, they state that the lower member of the Perham locally becomes indistinguishable from the upper member "near the eastern border of the [Presque Isle] quadrangle and [the rocks here] are mapped as undifferentiated Perham Formation" (Boucot and others (1964, p. 35). The writer did not find this situation to exist here. Rocks assigned by Boucot and others as belonging to undifferentiated Perham east of the fault (now recognized by the writer) and north of the latitude of Presque Isle (see pl. 1) actually belong to the Spragueville Formation. South of this approximate latitude, rocks mapped as undifferentiated Perham Formation by Boucot and others $(1964, \mathrm{pl} .1)$ actually belong to the upper member of the 
Perham. Thus, the lower member of the Perham Formation is not found east of the inferred north-south fault in the Presque Isle area, nor has it been recognized elsewhere farther south in the region (pl. 1). The lower member therefore appears to be a lenticular unit that reaches its maximum thickness near the vicinity of Mapleton (pl. 1) and that apparently thins and eventually wedges out to the east and southeast.

Lithology.-The lower member of the Perham is described as consisting mostly of "gray, greenish-gray or reddish-gray, fine-grained, nonmicaceous, generally noncalcareous argillite" (Boucot and others, 1964, p. 34). Some of the argillaceous rocks actually are shale and some are locally calcareous, especially near the gradational contact with the upper member. Manganese deposits of the oxide and carbonate facies (Pavlides, 1962, p. 50, 59) are localized in the lower member of the Perham in the northern manganese district as described by White (1943, p. 153-158) and Miller (1947, p. 42-61). However, in the stratigraphic sequence they recognized, such deposits occur in the lower member of the Aroostook Limestone of their usage as well as in the lower member of the unnamed unit overlying the Aroostook Limestone (White, 1943, pl. 24; Miller, 1947, pl. 2), These deposits are sedimentary lenses consisting of different proportions of manganiferous hematitic shales, ironstones, and siliceous carbonate rocks (Pavlides, 1962).

Thickness.-Boucot and others (1964, p. 37) did not assign separate thicknesses to the lower and upper members of the Perham. They thought the entire Perham averaged about 4,000 feet in thickness, although this was recognized as being a variable value. In the Presque Isle quadrangle near Mapleton the approximate thickness of the lower member of the Perham is about 2,000 feet.

Age.-Boucot and others (1964, p. 39-40) considered the lower member of the Perham to range in age between $\mathrm{C}_{4}-\mathrm{C}_{5}$ of the Llandovery through the Wenlock of the Silurian on the basis that the lower member of the Perham overlies the Frenchville Formation $\left(\mathrm{C}_{4}-\mathrm{C}_{5}\right.$ span of the Llandovery) and contains fossils no younger than Wenlock in age at one locality near the top of the unit. However, the fossil localities upon which the pre-Ludlow part of the age assignment was made are equivocal. Specifically, the fossil localities mapped within this unit by Boucot and others (1964) generally are in calcareous siltstone or sandstone, rock types which are not typical of the lower member of the Perham. The fossil localities at the top of the lower member of the Perham in the Presque Isle quadrangle (loc. 13 of pl. 1 and p. 39 of Boucot and others (1964)) are herein considered to be within the basal part of the upper member of the Perham Formation 
rather than in the upper part of its lower member and are not usable for directly dating the lower member of the Perham.

The occurrence of the lower part of the Perham above the Frenchville Formation of Llandovery $\mathrm{C}_{4}-\mathrm{C}_{5}$ age at the Castle Hill anticline (pl. 1) in the northwest part of the Presque Isle quadrangle suggests that its lower age limit here is late Llandovery $\left(\mathrm{C}_{4}-\mathrm{C}_{5}\right.$ or younger $)$ age. However, east of the Castle Hill area, the Frenchville is absent below the Perham. The lower member of the Perham here is in apparent conformable contact with the Carys Mills Formation. The age of the basal part of the Perham and its actual stratigraphic relationships with the underlying Carys Mills west and north of Presque Isle, however, are uncertain, and various interpretations are possible. Among these are:

(1) The age of the basal part of the Perham is Llandovery $A_{4}-B_{1}$. This age is based on presently available regional paleontologic information that the age of the Carys Mills is no younger than Llandovery $\mathbf{A}_{4}-\mathrm{B}_{1}$ (see table 2) and that the contact with the Carys Mills is entirely conformable (and probably gradational), as is the case for the contact between the Carys Mills and the Smyrna Mills Formations at locality 28 of plate 1.

(2) The Perham-Carys Mills contact is a disconformity, and the basal part of the Perham is distinctly younger than the Carys Mills, namely, post-early Llandovery, possibly as young as the age of the Frenchville (Llandovery $\mathrm{C}_{4}-\mathrm{C}_{5}$ ).

(3) The age of the upper part of the Carys Mills, where in contact with the Perham, may be younger than presently indicated by the fossils found within it; indeed it may be as young as the Frenchville (Llandovery $\mathrm{C}_{4}-\mathrm{C}_{5}$ ).

Hypotheses 2 and 3 are based on the absence of the Frenchville Formation between the Perham and Carys Mills and the fact that the Frenchville underlies the Perham in the Castle Hill area. In this report, however, the regional relationships and the presently available paleontologic data from the Carys Mills (hypothesis 1) are provisionally accepted for defining the nature and age of the Perham-Carys Mills contact. This interpretation is followed in the subsequent discussions and facies interpretation (see fig. 3). Hence, the basal part of the lower member of the Perham is considered to be time transgressing, being younger (Llandovery $\mathrm{C}_{4}-\mathrm{C}_{5}$ ) to the west (Castle Hill area) than along its contact with the Carys Mills (Llandovery $\mathbf{A}_{4}-\mathbf{B}_{1}$ age). The lower member of the Perham probably ranges in age, therefore, from approximately $A_{4}-B_{1}$ of the Llandovery to middle and possibly late Wenlock (see below). 


\section{UPPER MEMBER OF THE PERHAM FORMATION}

The upper member of the Perham is not directly involved with the stratigraphic relationship of the Carys Mills Formation, and it is not described in this report. It should, however, be pointed out that because of the stratigraphic and age relationships of the lower member of the Perham described above, the age of the upper Perham, originally assigned an early Ludlow age, is herein considered to span late Wenlock and early Ludlow time of the Silurian.

The paleontologic evidence for a latest age limit of early Ludlow for the upper part of the Perham is summarized by Boucot and others (1964, p. 37-39) and will not be discussed here. However, a brief review will be made of the more recent paleontologic data concerning the maximum age of the bottom part of the upper member, insofar as it relates directly to the age range of the lower member of the Perham that underlies it.

As discussed above, the sandy rocks that yield Wenlock-age fossils (Boucot and others, 1964, pl. 1, fossil loc. E-13) are herein assigned to the upper member of the Perham (loc. 12 of pl. 1). For similar lithologic reasons, the sandy-facies rocks 8.6 miles $\mathrm{N}$. $5^{\circ} \mathrm{W}$. from the community of Perham that contain Wenlock-age fossils and that Boucot and others $(1964$, p. 40$)$ have placed in the lower member of the Perham are also herein considered to be within the upper member of the Perham.

Additional collections from locality 12 (U.S. Geol. Survey 7575 SD) of plate 1 (loc. E13 of Boucot and others, 1964) have yielded ostracodes and trilobites. The ostracodes have been examined by J. M. Berdan of the U.S. Geological Survey who identified (written commun., 1965) :

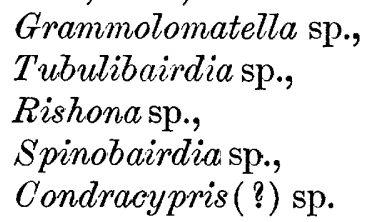

The above genera generally have rather wide age ranges, but Berdan feels that in averaging all these ranges, this collection is probably not younger than Henryhouse (early Ludlow) or older than Waldron (late Wenlock).

The trilobites from this collection were examined by A. R. Palmer of the U.S. Geological Survey in consultation with H. E. Whittington of Harvard University and Kenneth Campbell of the Australian National University. "They identified a Phacops of the $P$. orestes group and a species of Diacalymene, in addition to other elements that were most suggestive to them of a late Llandovery age. They couldn't 
exclude the possibility of a Wenlock age, but they said that the assemblage definitely couldn't be as young as Ludlow" (A. R. Palmer, written commun., 1966).

Therefore, based on the ostracode and trilobite collections from locality 12 of plate 1 , the basal beds of the upper member here are most likely of late Wenlock age. The underlying lower member of the Perham is older, though it may also, in part, be of late Wenlock age.

\section{OTHER SEDIMENTARY PALEOZOIC UNITS}

\section{CAMBRIAN(?) TO PENNSYLVANIAN (?) ROCKS (UNDIFFERENTIATED)}

Mars Hill area, Maine.-The monadnock formed by Mars Hill is undierlain by granule and pebble conglomerate and green impure quartzite layers. The stratigraphic position of these rocks and of the generalized area of slate and siltstone immediately to the east in New Brunswick (south of Listerville) is not known. Bedding is sparse in the rocks of Mars Hill; where present, it is generally vertical and lacks features to determine the top-facing directions of strata. Hence, it is not clear whether the rocks of Mars Hill are part of a syncline or an anticline. However, northeast of Mars Hill, bedding in the Carys Mills Formation dips consistently toward the north. If the rocks of Mars Hill and the Carys Mills Formation are not separated by a fault here, then the northward dip of strata in the Carys Mills in this region implies that the Carys Mills overlies the rocks on Mars Hill. On this evidence, the rocks on Mars Hill are older than the Carys Mills. Because only the upper part of the Carys Mills is of Early Silurian age, the rocks of Mars Hill are probably of Ordovician or older age rather than Early Silurian.

Crinoidal debris in sparse amounts is the principal type of fossil found at a few places in conglomerate on Mars Hill. In addition, Preston E. Cloud, Jr., of the U.S. Geological Survey, reported (unpub. data, 1941) that at one place on Mars Hill he found some bryozoans with crinoidal debris. It has not been possible to recover these bryozoans in order to reexamine them and possibly to date these rocks more closely. Nonetheless, their presence along with the crinoids suggests a post-Cambrian age. On the basis of limited structural and paleontologic data, therefore, the rocks on Mars Hill are provisionally considered to be of Ordovician age and to underlie the Carys Mills Formation. Thus, they may be a coarser clastic equivalent to the Chandler Ridge Formation to the southwest (pl.1).

Woodstock region, New Brunswick.-A great variety of rocks of different ages occurs on the southeast side of the major northeasttrending fault that is inferred near Woodstock, New Brunswick (pl. 1). North of the St. John River, these rocks are chiefly red conglom- 
erate, sandstone, and shale of Pennsylvanian age (Anderson, 1956). South and west of the St. John River, near Wakefield, New Brunswick, are a few scattered outcrops of red sandstone and conglomerate that resemble the Mapleton Sandstone (Middle Devonian) of Maine (Pavlides, 1966a). The relationships of these Mapleton-like rocks with what are generally believed to be older rocks south of the Wakefield area and east of the fault is not known. They may unconformably overlie the older rocks as the Mapleton does in Maine or they may locally be in fault contact with them. The rocks assigned a Pennsylvanian age by Anderson (1956) south of Ashland, New Brunswick, are believed to be in fault contact with the Carys Mills Formation; bedding in the Devonian(?)-Carboniferous "red beds" near the contact dips gently toward the steeply dipping strata of the Carys Mills Formation. There does not seem to be enough space between the "red beds" and the Carys Mills to permit a reversal of dip in the "red beds" that would place them in direct unconformity upon the Carys Mills here.

Rocks older than the "red beds" on the southeast side of this inferred fault are chiefly various types of quartzite and slate. Some of the slate locally is red or maroon and resembles parts of the Smyrna Mills Formation in Maine (Pavlides and Berry, 1966, p. B53-B54). Much of the terrane from about the latitude of Woodstock south and extending east toward Melville, New Brunswick, is underlain by rocks assigned a pre-Silurian age by Anderson and Poole (1959).

\section{CAMBRIAN(?) TO SILURIAN(?) ROCKS (UNDIFFERENTIATED)}

Cambrian(?) to Silurian(?) terrane, approximately in the westcentral part of figure 1, consists of a great variety of rocks. The northeasternmost areas underlain by the Cambrian(?)-Silurian(?) unit of plate 1 contain the Nine Lake and the Dunn Brook Formations of Ordovician or Silurian age or both (Pavlides, 1964). The Nine Lake Formation consists of gray-green and green slate interlayered with graywacke and conglomeratic graywacke. It locally contains lentils of (1) red and purple slate, (2) conglomeratic graywacke, and (3) metaperlite.

The Dunn Brook Formation is chiefly composed of metavolcanic rocks that include keratophyre, tuff, volcanic breccia and conglomerate, metaperlite, pillow lavas, and other silicic and intermediate volcanic rocks. Clastic sedimentary rocks are in places also interbedded with the volcanic rocks.

The Weeksboro-Lunksoos Lake anticline (pl. 1) is cored chiefly by the Dunn Brook Formation of Ordovician or Silurian age and the Grand Pitch Formation of Cambrian(?) age. The Grand Pitch extends southwestward from about the latitude of Weeksboro (Pavlides 
and others, 1964, fig. 1). As originally described, it consists chiefly of "quartzite and slate, interbedded in varying proportions and contains red slate with Oldhamia smithi Ruedemann" (Neuman, 1962, p. 794). Near Weeksboro, however, it consists mostly of phyllite with thin quartzite interbeds and massive thick-bedded quartzite with thin phyllitic interbeds; volcanic rocks are present at a few places (Pavlides and others, 1964, p. C28).

North of Weeksboro, the nose of the Weeksboro-Lunksoo Lake anticline is composed of the Dunn Brook Formation (Pavlides and others, 1964, pl. 1). In this terrane, north of Smith Brook (fig. 1), granule-tocobble conglomerate containing volcanic clasts similar to those of the Dunn Brook is present at a few places above the Dunn Brook.

\section{ORDOVICIAN ROCKS}

UNDIVIDED ROCKS

The Castle Hill anticline (pl. 1) is cored by a diverse assemblage of rocks that are shown as an undivided unit. Except for a small area at the north end of the anticline, these rocks compose an unnamed unit about 3,000 to 4,000 feet thick that consists of silicic and intermediate volcanic rocks, black chert, argillite, and black shale and slate (Boucot and others, 1964, p. 17-20). An outcrop of black slate near the top of this unit yielded graptolites of Middle Ordovician age in the zone of Orthograptus truncatus var. intermedius which is the same age as the graptolites in the Carys Mills Formation at locality 1 of plate 1.

At the north end of the Castle Hill anticline a calcareous blue-gray to blue-green sandstone that locally contains lithic clasts is present. In places, it is interbedded with green argillite and pebble conglomerate layers. The relationship of these rocks to the underlying volcanic rocks is not known, but fossils found at a few places within these rocks (for example, loc. 7, pl. 1) indicate that some of these rocks may be of Late Ordovician age (Boucot and others, 1964, p. 30).

The undivided Ordovician unit in the Howe Brook quadrangle about 10 miles west of Monticello, Maine (pl. 1), is, in general, lithologically similar to that of the Castle Hill area. It consists of an undetermined thickness of interbedded volcanic rocks, graywacke, slate, and black carbonaceous chert. Carbonaceous argillite partings in the chert have yielded a graptolite fauna in the interval of Zone 12 of the Caradoc (Wilderness or Black River) or that of Climacograptus bicornis. The fauna from locality 23 (U.S. Geol. Survey CO 6009) has been identified by W. B. N. Berry (written commun., 1961) and contains:

Climacograptus bicornis (Hall),

C. eximius Ruedemann?, 
C. sp.,

Cryptograptus tricornis (Carruthers),

Didymograptus sagitticaulis Gurley?,

Dicellograptus sp.,

Dicranograptus contortus Ruedemann,

Glyptograptus teretiusculus (Hisinger)?,

G. sp.,

Leptograptus sp.,

Nemagraptus exilis (Lapworth),

Orthograptus calcaratus var. acutus (Lapworth).

PYLE MOUNTAIN ARGILITE

The Pyle Mountain Argillite as mapped and described by Boucot and others (1964) occurs along the east flank of the Castle Hill anticline as well as at different places near the north end of this fold (pl. 1). It is about 600 feet thick and typically is a fine-grained olivegreen noncalcareous argillite. In its northern outcrop area, however, it is gray green and somewhat calcareous. It has yielded shelly fossils, at few places, that generally date the argillite as Ashgillian; the brachiopod genera "do not date these rocks more closely than the latter half of the Ordovician period. *** The more critical fossils for correlating these beds with the Ashgillian seem to be the trilobites as reported by Whittington" (R. B. Neuman in Boucot and others, 1964, p. 23).

\section{ORDOVICIAN AND SILURIAN(?) ROCKS}

Scattered exposures of green phyllite and dark-gray to black slate that is slightly carbonaceous occur east of Hodgdon and at Hovey Hill, Maine (pl. 1). Because of the limited nature of these exposures, their precise distribution and the relationship of the green phyllite and black slate to each other as well as to the enclosing rocks are not known. For purposes of this report they are grouped as an undivided unit of unknown thickness. These rocks have yielded poorly preserved graptolites of Middle and Late Ordovician age (W. B. N. Berry, written commun., 1961) at two places. Locality 36 (U.S. Geol. Survey CO 3193) contains :

Climacograptius (?) sp.,

Diplograptus (?) sp.,

?Hallograptus bimucronatus (Nicholson)

Leptograptus sp.

Locality 33 (U.S. Geol. Survey CO 3194) contains:

Climacograptus phyllophorus Gurley,

C.sp.,

Didymograptus (?) sp., 
Glossograptus (?) sp.,

Glyptograptus euglyphus (Lapworth),

Leptograptus sp.

According to W. B. N. Berry, the age of the assemblage from locality 36 is probably the latter half of the Middle Ordovician, whereas the collection from locality 33 is in the interval of graptolite Zones 11 (Nemagraptus gracilis) or 12 (Climacograptus bicornis); that is, about equivalent to Porterfield and Wilderness, or both.

Some of the green phyllite and slate of this unit resembles the lower part of the Smyrna Mills Formation of Silurian age, and the unit is hence provisionally assigned an Ordovician and Early Silurian(?) age. If manmade exposures become available in this terrane in the future, the problem may then be resolved of whether these slates and phyllites are indeed part of the Smyrna Mills or actually interbedded with the rocks known to be of Ordovician age.

SILURIAN ROCKS

FRENCHVILLE FORMATION

The Frenchville Formation as mapped and described by Boucot and others (1964, p. 31-33 and pl. 1) crops out along the north and west sides of the Castle Hill anticline. Its distribution in this area has been revised by David Roy (unpub. data) of the Massachusetts Institute of Technology from the map relationships originally shown by Boucot and others. However, these revisions do not affect the original stratigraphic relationships and, for purposes of this report, the Frenchville as mapped by Boucot and others is shown on plate 1 .

The Frenchville is a lenticular unit that can be as much as 1,100 feet thick (Boucot and others, 1964, p. 32) and that is composed chiefly of graywacke and conglomerate. Lithic clasts in the graywacke and conglomerate beds of the Frenchville are generally fragments of volcanic rocks and chips of chert and slate (Boucot and others, 1964, p. 31-32 ; see also under "Sheridan Sandstone" ${ }^{1}$ of Williams and Gregory, 1900, p. 132-133).

The age of the Frenchville is Llandovery $\mathrm{C}_{4}-\mathrm{C}_{5}$. This age is based on at least two collections of brachiopods from the Frenchville Formation in the Ashland and Caribou quadrangles that, respectively, are immediately west and north of the Presque Isle quadrangle (Boucot and others, 1964, p. 33).

\footnotetext{
I The name Sheridan of the usage of Williams and Gregory (1900) had been preempted by earlier usage and the name Frenchville is now assigned to this unit (Boucot and others, 1964, p. 31).
} 
For purposes of this report, a wide variety of formations and rock types of Silurian or Devonian age or both have been lumped into one Silurian and Devonian map unit (pl. 1). However, all rocks of this unit in direct contact with the Carys Mills Formation are of Silurian age. Some of the units discussed below as Silurian are well dated, other units contain only a few scattered fossil localities, and the contiguous terrane may actually contain rocks as young as Devonian.

\section{SILURIAN}

Southern part of the area

The southern end of the Carys Mills outcrop area around the southwestern nose of the Aroostook-Matapedia anticlinorium, from about Oakfield, Maine, eastward to the International Border near Houlton is bounded by the Silurian Smyrna Mills Formation that ranges from early Llandovery into the early Ludlow (Pavlides and Berry, 1966). The Smyrna Mills Formation consists dominantly of quartzite, siltstone, and slate with local lenses of ferruginous manganese deposits and red and maroon slate and siltstone. The lower part of the Smyrna Mills at several places is composed chiefly of slate. The Smyrna Mills has been traced between the Houlton, Maine, and Woodstock, New Brunswick, areas by reconnaissance and appears to be in a complex southwest-plunging syncline (Pavlides, 1966a). Fossils that have been found within the Smyrna Mills in New Brunswick generally span the same age range as those reported for the Smyrna Mills in Maine (Pavlides and Berry, 1966).

The oldest of these (loc. 38 of pl. 1) consists of deformed graptolites in a black carbonaceous and pyritic slate. From this locality W. B. N. Berry has identified:

Climacograptus cf. C. scalaris (Hisinger),

C. scalaris var. normalis Lapworth?,

Monograptus sp. (curved rhabdosome and hooked thecae).

According to Berry (written commun., 1964), "the occurrence of two forms similar to $C$. scalaris together and with this kind of monograptid suggest the early part of the Llandovery-possibly about Zone 19."

Locality 37 (pl. 1) of Wenlock age has been described elsewhere (Pavlides and Berry, 1964, p. B59, table 2) and will not be discussed here.

Locality 34 (pl. 1) consists of rusty-to-orange-weathered siltstone that has yielded the following graptolites:

Monograptus colonus var. compactus Wood,

M. dubius Suess, 
$M$.cf. $M$. uncinatus Tullberg,

$M$. aff. $M$. vicinus Perner,

$M$. sp. (of the $M$. tumescens type).

W. B. N. Berry who studied and identified this collection dates it as early Ludlow age, in the zone of Monograptus nilssoni and Monograptus scanicus. $^{2}$

Locality 35 (pl. 1) which was also studied and dated by W. B. N. Berry is of the same age and graptolite zone as locality 34 . Actually, two types of fossiliferous rocks are present at locality 35. A mediumbedded buff-weathered limestone at the east end of a roadside exposure contains only fragmental dendroids. The slate and siltstone on the west end of the exposure yielded:

Monograptus colonus cf. var. compactus Wood,

$M$. cf. M. dubius (Suess),

$M$. scanicus Tullberg (?),

$M$. tumescens var. contus Berry,

$M$.sp. A (of Berry 1964),

$M$. sp. (of the $M$. colunus group),

$M$. sp. (of the $M$. tumescens type).

Locality 24 (pl. 1) consists of coral clasts in a polymict conglomerate. These corals have been examined by W. A. Oliver, Jr. (written commun., 1965), who finds they are strikingly similar to: Favosites (=Astrocerium) intermittens magnum Stumm, 1963, and Heliolites interstinctus occidentalis Stumm, 1963. According to Oliver, these corals, which were described from the Hardwood Mountain Formation (Stumm, 1962, p. 5), are common in rocks of Ludlow age in Maine and Quebec. Oliver feels that the most conservative date that can be assigned these corals is Silurian or Devonian, but he favors a Ludlow age. If these coral clasts are indeed of Ludlow age, then the host polymict conglomerate is also of Ludlow or younger (up to Devonian) age. A Ludlow age and the proximity of this locality to the contact with the Carys Mills Formation, which may be as young as Early Silurian here (for example, loc. $25, \mathrm{pl} .1$ ), suggests that there may be some structural or stratigraphic complication near this locality not presently recognized by the reconnaissance mapping carried out in this area (Pavlides, 1966a).

West-central part of the area

The Maple Mountain Formation of Silurian age (Pavlides, 1964) is centered about 10 miles southwest of Bridgewater and is inferred

\footnotetext{
2 The zonal designation Monograptus nilssoni and Monograptus scanicus is used for oarly Ludlow graptolite collections in the northern Appalachians as the correlative of graptolite zones 33 and 34 of the British Silurian of Elles and Wood (1901-18) and of equivalent zones in continental Europe (Pavlides and Berry, 1966, p. B60).
} 
to be in fault contact on its east side (pl. 1) with the Burnt Brook Formation and the Bell Brook Formation (not differentiated within DSu unit of pl. 1). It is estimated to be about 6,000 feet thick, and it contains several hundred feet of graywacke and conglomeratic graywacke at its base, above which the rocks are mostly slate containing sparse clastic rock interbeds (Pavlides, 1964, p. B5). Lenticular manganese deposits 10-150 feet thick occur about 5,000 feet above its base (Pavlides, 1962).

A thin sequence of Silurian rocks about 1,000 feet thick also occurs along the west side of the Weeksboro-Lunksoos Lake anticline on Howe Brook Stream (loc. 22 of pl. 1). These rocks are overlain by the Seboomook Formation of Devonian age and are inferred to be underlain by the Dunn Brook Formation of Ordovician or Silurian age, although the Dunn Brook is not exposed here. The fauna from locality 22 , was dated as late Llandovery $\left(\mathrm{C}_{3}\right)$ to Ludlow by A. J. Boucot (written commun., 1962) who identified the following brachiopods :

\section{Atrypa reticularis, "Chonetes"sp., \\ Howellella sp. \\ Isorthis (?) sp., \\ Protathyris sp., \\ Sphaerirhynchia sp., \\ orthotetacid, \\ unidentified brachiopods.}

The age of this collection was interpreted from "the presence of Protathyris sp. which thus far in North America has not been obtained from beds of Devonian age, although in the Old World it is known from the Lower Gedinnian [lower Helderbergian]" (A. J. Boucot, written commun., 1962).

\section{Northeastern part of the area}

West of the town of Mars Hill are two additional Silurian fossil localities within the Silurian and Devonian unit of plate 1. The rocks here are chiefly siltstone, quartz graywacke, and slate (Pavlides, 1964, p. 27-28). Locality 18 (U.S. Geol. Survey loc. 6836-SD) in limy siltstone consists of brachiopods, among which is Isorthis cf. I. arcuaria. This locality was discovered by Mr. William Forbes of Washburn and was submitted to A. J. Boucot for examination and dating. Boucot (written commun., 1963) considered the fauna from here to be of early Ludlow age.

A graptolite fauna has more recently been found by the writer at locality 17 (U.S. Geol. Survey, loc. 7707-SD) in orange-weathered 
siltstone similar to that characteristic of the upper member of the Perham Formation. The fauna here has been examined by W. B. N. Berry who recognized the following graptolites:

Monograptus chimaera (Barrande),

$M$. colonus var. compactus Wood,

$M$. crinitus Wood,

M. dubius Seuss,

$M$. forbesi Berry,

M. nilssoni (Barrande)?,

$M$.sp. (of the M.dubius type).

According to Berry, this assemblage is of early Ludlow age in the interval of the zone of Monograptus nilssoni and Monograptus scanicus.

The presence of two fossil localities of early Ludlow age in close proximity to the Carys Mills Formation here is at present enigmatic. Possibly the structural and stratigraphic relationships in this heavily wooded terrain with few outcrops are more complex than reconnaissance geology suggests. One possible explanation is that the preLudlow rocks between these fossil localities and the Carys Mills contact represent a compressed stratigraphic section. An alternative speculation is that the upper part of the Carys Mills here may range upwards in age into the Wenlock, rather than being of Llandovery age.

The syncline cored by the Silurian rocks in New Brunswick between the communities of Carlingford and Listerville (pl. 1) consists chiefly of green quartzite, siltstone, and slate. Locally, some impure limy beds are also present. Locality 15 ( $\mathrm{pl} .1$ ) has thus far yielded the only fossils that can be closely dated. They are graptolites that occur within a section of orange-weathered thin-to heavy-bedded calcareous siltstone and quartzite along a small roadcut. These rocks closely resemble those that characterize the upper member of the Perham Formation in Maine. The fauna from locality 15 was studied by W. B. N. Berry who considers it to be of early Ludlow age in the zone of Monograptus nitssoni and Monograptus scanicus. He has identified the following monograptids from here:
Monograptus bohemicus (Barrande)?,
$M$. cf. M. crinitus Wood,
$M$. cf. $M . d u b i u s$ Suess,
M. forbesi Berry?
$M$.sp. (of the $M$. colonus type).

Pelmatazoan debris was also noted at a few places near the graptolites at this locality.

Locality 16, north of Listerville, New Brunswick, consists of fragmental shelly debris in a few thin layers, up to 2 inches thick, in a 
section of impure limestone along a roadcut. A collection from here, in addition to other fragmental shelly material, has also yielded some cystoid plates that may be of Silurian age (A. J. Boucot, written commun., 1964).

Rocks of Silurian age on the east side of the Carys Mills Formation in New Brunswick include many diverse lithologies. An orangeweathered, generally thick-bedded calcareous siltstone and impure silty limestone that is probably in fault contact with the Carys Mills Formation extends from at least Tobique Narrows southward to about Perth, New Brunswick. At locality 13 (pl. 1), Naylor and Boucot (1965, p. 163) report that P. E. Cloud, Jr., of the U.S. Geological Survey, recognized Conchidium, and they regard this locality as of Silurian age. Fossils from locality 14 (pl. 1) from the same belt of rocks could not be dated more closely than Silurian by A. J. Boucot (written commun., 1964).

The rocks east of the limy strata described above are generally medium-bedded green quartzite and slate. These rocks are well exposed along the road on the north side of the Tobique River east of fossil locality 13 (pl. 1). The precise distribution and areal extent of these rocks is not known.

\section{East-central part of the area}

The presence of manganese deposits near Glassville, New Brunswick (Caley, 1936, map 380A; Anderson, 1956), suggests that the Silurian-Devonian belt from about Glassville south may belong to the Smyrna Mills Formation or some formation equivalent to it. The Silurian Smyrna Mills Formation in Maine (Pavlides and Berry, 1966, p. B53-B54) and similar rocks in New Brunswick contain the known manganese deposits of the region. Hence, the Silurian-Devonian rocks south of approximately the latitude of Glassville may in large measure be of Silurian age. In the region approximately between Knowlesville and Howard Brook, New Brunswick, Caley (1936, map 380A and p. 8) reported four fossil localities of probable Silurian age. In addition, at locality 20, near Riverbank, New Brunswick, fossils discovered by Lee (1962, map 25) have been dated as of Silurian age by L. M. Cumming of the Geological Survey of Canada (written commun., 1961) on the basis of Calymene sp. cf. C. blumenbachi (Brongniart) which he recognized in Lee's collection from this locality. Ells $(1876$, p. 99 and map) also reported the presence of iron-bearing strata on the west bank of the St. John River southwest of Riverbank. The lithology at locality 20 consists chiefly of limy siltstone and slate; at one place a red hematitic limestone that contains sparse crinoidal debris is also present. Similar red hematitic limestone occurs near locality 18 west of Mars Hill in Maine. 
The fossils at locality 21, northwest of Peel, New Brunswick, occur in a limestone exposed along the north ditch of the Peel-Lansdowne Road. Several fossil collections have been reported on from this locality. A collection by Lee (1962, map 25) has been studied by L. M. Cumming of the Geological Survey of Canada who recognized Aulacopleura (Aulacopleura) konincki var. konincki (Barrande) and stated (written commun., 1961) "The stratigraphic range of the subgenus (which has not been previously reported from North America) is limited to the Silurian and Lower Middle Devonian. The variety konincki occurs in the Upper Wenlockian of Bohemia."

Another collection from locality 21 has been studied by A. R. Palmer of the U.S. Geological Survey who felt that the fragments of a large trilobite in this collection were "referable to the typical subgenus of Cheirurus, that is Cheirurus (Cheirurus)" (written commun., 1965). In addition to this trilobite, the collection has yielded platyceratid gastropods and some long-ranging conodonts. The age of this collection is probably Silurian. "Cheirurus (Cheirurus) is listed as having a range from Late Ordovician through Silurian. Ellis Yochelson [U.S. Geological Survey] looked at the gastropods and said they were most likely Silurian or Devonian with a bias in favor of Silurian. Thus the combination of information seems to put the emphasis on Silurian as the probable age of the sample" (A. R. Palmer, written commun., 1965).

Less well dated rocks of the Silurian-Devonian unit in contact with the Carys Mills Formation include the slate member of the Bell Brook Formation. This unit occurs in the western part of the Bridgewater quadrangle, Maine (Pavlides, 1965, p. 30-33), and consists chiefly of slate and siltstone and minor amounts of graywacke and conglomerate. From its northernmost exposure, about 5 miles southwest of Bridgewater, (pl. 1) the slate member extends southward into the Houlton quadrangle where it may merge in with the Smyma Mills Formation, with which some of the unit may be coeval.

DEVONIAN

Northwestern part of the area

Paleontologically dated rocks of Devonian age in the Silurian and Devonian unit of plate 1 occur only in Maine. The most diverse lithology and greatest age range of these rocks are found in the Presque Isle quadrangle (pl. 1), which has been described by Boucot and others (1964). The youngest formation is the Mapleton Sandstone of upper Middle Devonian (early Givetian) age (Boucot and others, 1964, p. 61; Schopf, 1964, p. D49). The Mapleton Sandstone, which actually grades upwards from a red conglomerate to mostly a green 
sandstone, occurs in an oval north-trending syncline and unconformably overlies older Devonian as well as Silurian rocks (Boucot and others, 1964, pl. 1). The east flank of this Mapleton syncline, however, is now inferred to be in fault contact with the Spragueville Formation of Llandovery to Wenlock(?) age.

Except for its north side, where it overlies some Silurian rocks, the Mapleton elsewhere overlies rocks of the Dockendorff Group (Boucot and others, 1964, pl. 1). The lower part of the Dockendorff Group consists of the Hedgehog Formation that is made up chiefly of trachyte, rhyolite, and andesite with some interlayered sedimentary rocks (Boucot and others, 1964, p. 40-46). Tuffaceous rocks from the Hedgehog contain brachiopods of Helderberg (New Scotland) or upper Gedinnian age. The upper part of the Dockendorff Group consists of three formations that are believed to be lithofacies and temporal equivalents of each other. They are the Edmunds Hill Andesite, the Chapman Sandstone, and the Swanback Formation (Boucot and others, 1964, p. 46-60). The Swanback, which consists mostly of shale and slate, in fact is for the most part structurally below the sandstones of the Chapman (Boucot and others, 1964, pl. 1) and therefore is not equivalent to all the Chapman into which it is stated to grade or merge (Boucot and others, 1964, p. 58). The lower part of the Swanback contains some fragmental volcanic rocks as well as what may be felsite flows or sills comparable to felsites of the Hedgehog Formation (Louis Pavlides, unpub. data). The lower part of the Swanback, therefore, may be coeval, in part, with the Hedgehog Formation. The southern and southwestward extent of the Swanback Formation is not known because of the scarcity of outcrops in this general area. However, the northwestern part of the Howe Brook quadrangle (inset of pl. 1) as well as the terrane near Howe Brook (pl. 1) is underlain by cyclically graded quartzite-pelite layered rocks typical of one facies of the Seboomook Formation (Boucot, 1961, p. 170). The Seboomook, in general, appears to range in age from upper Gedinnian (New Scotland) to Siegenian (Oriskany). In part, therefore, the Seboomook is coeval with the Swanback Formation (New Scotland age), with part of which it may grade or merge. Green slate mantles the Dunn Brook Formation (Ordovician or Silurian age) along part of the northern end of the WeeksboroLunksoos Lake anticline (pl. 1), and this slate with brachiopods of New Scotland age (A. J. Boucot, written commun., 1965) is probably also a coeval lithofacies of the Seboomook Formation.

South-central part of the area

Rocks having New Scotland age faunas occur at Littleton Ridge and along Twin Brooks, respectively about 5 and 7 miles northwest of 
Houlton, Maine. These two localities represent the easternmost dated Devonian rocks of plate 1.

The quartzite and slate sequence east of the Silurian rocks at Tobique Narrows, New Brunswick, may be of Devonian age in that they bear some resemblance to Devonian rocks elsewhere in Maine. However, this age is a tenuous correlation, and they may well be other than Devonian in age.

\section{INTRUSIVE ROCKS}

Intrusive rocks having a wide range in composition locally intrude and thermally metamorphose many of the stratigraphic units of plate 1. Only a few of the larger intrusions are shown on plate 1 . West of Houlton are five small granitic plutons; another granitic pluton occurs 5.5 miles northwest of Presque Isle (pl. 1). Garnet porphyry occurs in two small plutons about 2.5 and 6 miles southwest of Bridgewater (pl. 1). A north-trending 5-mile-long rhyodacitic dike crops out 2.5 miles west of Monticello (pl. 1). This dike appears to be mantled by felsites at its north end (Pavlides, 1965, p. 41-42).

Not shown on the map are numerous other dikes of various compositions. A small cluster of teschenite dikes occurs 1.5 miles southeast of Mapleton (Boucot and others, 1964, pl. 1). Dark dikes, many of which may be basaltic in composition, are abundant north of Mars Hill as well as east of the general latitude of Mars Hill. They cut all lithologies in this general region. Rocks of this general type probably support the ridges between Bristol and Oakland in New Brunswick (pl. 1).

\section{FACIES RELATIONSHIPS}

The Carys Mills Formation, which constitutes the core rock of the Aroostook-Matapedia anticlinorium over much of its length, is now known to span a considerable interval of early Paleozoic time and also to have a great variety of facies changes in stratigraphically lateral and vertical directions. The following discussion of the stratigraphic and facies relationship of the Carys Mills Formation is generally confined to the area of plate 1 .

\section{ORDOVICIAN}

The Ordovician part of the Carys Mills in the Presque Isle area is the temporal equivalent of the eugeosynclinal assemblage of slate, graywacke, and chert along the Castle Hill anticline which contains graptolites (loc. 10, pl. 1) in the interval of Orthograptus truncatus var. intermedius, or Zone 13 (Boucot and others, 1964, p. 19-20). This 
Caradocian graptolite zone also occurs in the Carys Mills Formation near Colby (loc. 1 of pl.1).

The actual relationships of the rocks of the Carys Mills that are of the same age as the eugeosynclinal Ordovician rocks of the Castle Hill area are not known because these time-equivalent, but dissimilar, suites of rocks are everywhere separated by the Perham Formation (pl. 1 and fig. 3).

An analogous situation exists near the southern end of the Aroostook-Matapedia anticlinorium between the Carys Mills Formation and eugeosynclinal rocks in the Howe Brook quadrangle that enclose locality 23 of figure 1. These eugeosynclinal rocks are also probably coeval, in part, with the Caradocian age part of the Carys Mills in similar manner to the rocks of the Presque Isle-Castle Hill area.

The Pyle Mountain Argillite of Ashgillian age that overlies the Castle Hill rocks of Caradocian age also is probably equivalent to the Upper Ordovician part of the Carys Mills as, for example, at locality 6 of plate 1. According to W. B. N. Berry (written commun., Sept. 22, 1966) there is "only one specimen that can be identified in the collection [and] is Orthograptus truncatus var. socialis (Lapworth). This zone is confined to Zone 15, the Dicellograptus complanatus var. ornatus Zone in North America. As far as I know, it is confined to the latest Ordovician graptolite zone-or at least beds correlative with the North American $D$. complanatus var. ornatus Zone-in Europe. This seems to be the first record of a clearly Latest Ordovician graptolite from the eastern U.S." Thus, in the Middle and Late Ordovician, a western eugeosynclinal suite of rocks was accumulating in the Castle Hill and Howe Brook regions at the same time that the calcareous rocks of the Carys Mills were being deposited to the east.

The suite of black and gray slate and green phyllite of Middle and Late Ordovician age on the southeastern and eastern side of the Aroostook-Matapedia anticlinorium (within OSu unit east of Hodgdon and at Hovey Hill of pl. 1) also is, in part, coeval with the Carys Mills. Thus, in about the same general span of time, a different depositional environment, free of volcanism, prevailed on the eastern side of the basin in which the Middle Ordovician part of the Carys Mills was being deposited, in contrast to the eugeosynclinal assemblage on the western side of the basin.

\section{SILURIAN}

The ribbon limestones of the Carys Mills Formation continued to be deposited without any recognizable change in the conditions of sedimentation up into the uppermost part of the lower Llandovery and 
into the basal part of the middle Llandovery. The evidence for this sedimentation history is at the south end of the Aroostook-Matapedia anticlinorium. In the Houlton and Smyrna Mills area, the contact between the Carys Mills Formation and the overlying Smyrna Mills Formation, as exposed in a roadcut near Timony Lake, is gradational. Here graptolites near the base of the Smyrna Mills and near the top of the Carys Mills (loc. 27 and 28 of pl. 1) are of Zone 19 age or in the interval $\mathbf{A}_{4}-\mathbf{B}_{1}$ of the Llandovery (Pavlides and Berry, 1966). The presence of graptolites of Zone 18 age or $\mathbf{A}_{4}$ of the Llandovery within the Smyrna Mills Formation at locality 26, suggests that the original depositional contact here may also locally be intertonguing as well as gradational, as schematically shown in figure 2 .

The region from about the longitude of the Castle Hill anticline eastward to the town of Fort Fairfield, Maine, contains the most lithologic and paleontologic evidence for understanding the facies relationships of the Carys Mills Formation. Figure 3 schematically illustrates these relationships in this region.

The contact of the Carys Mills Formation with the Spragueville Formation in northern Maine is not precisely defined because it is gradational. The thin gray-blue limestone layers typical of Carys Mills lithology occur at a few places interbedded with silty limestone and limy siltstone near the base of the Spragueville. Elsewhere, near the contact, the limy rocks of the Carys Mills and Spragueville become so similar in appearance that it is difficult to assign such rocks objectively to either formation with any great certainty.

The precise nature of the contact between the Carys Mills and lower member of the Perham Formation is uncertain, as described earlier. It maps locally as a conformable contact and, by analogy with the better known relations of the Carys Mills-Smyrna Mills contact, the

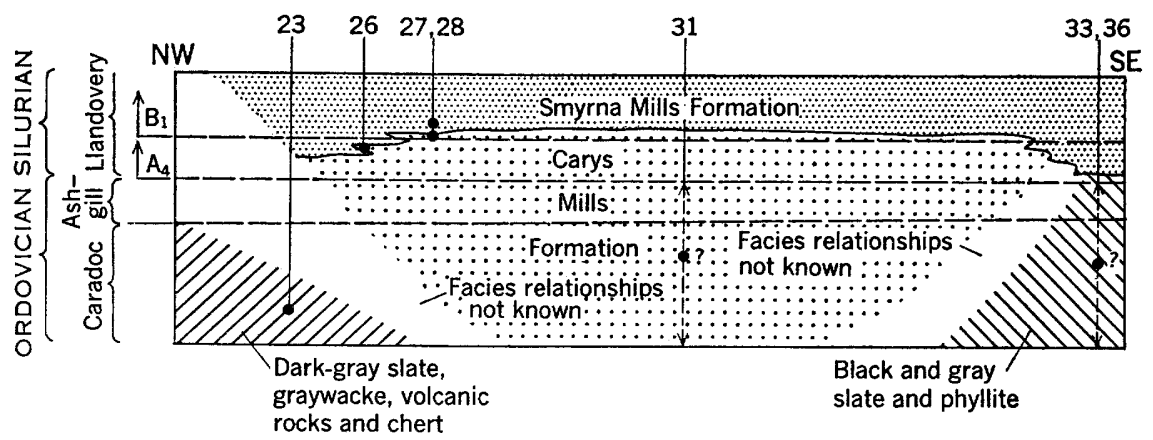

Figure 2.-Generalized facies relationships before deformation of the Carys Mills Formation and other formations between South Brook and East Hodgdon areas, Maine. Fossil locality numbers are those shown on plate 1. 


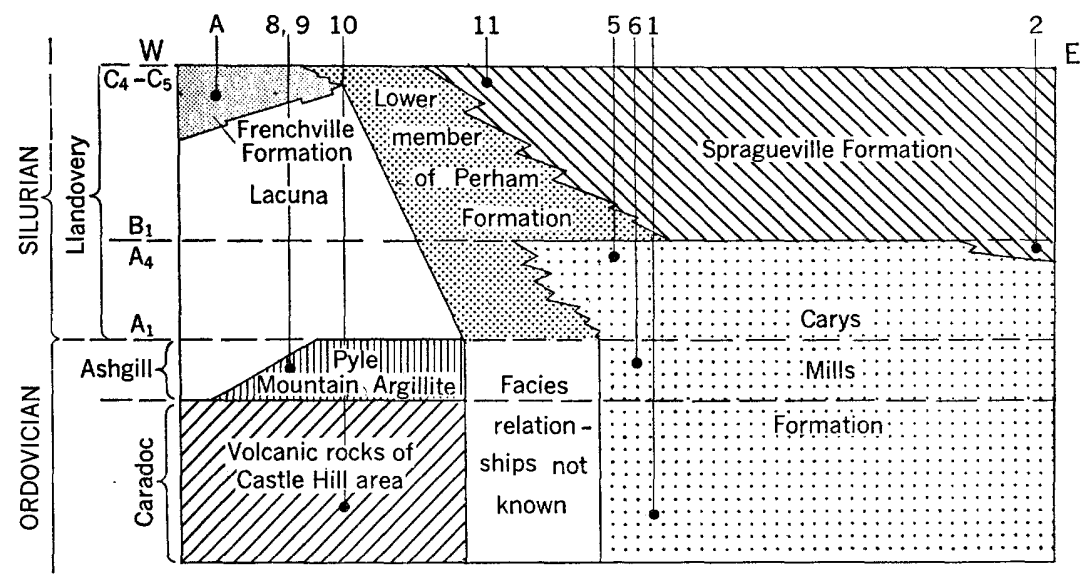

Figure 3.-Generalized facies relationships before deformation of the Carys Mills Formation and other formations between the Castle Hill and Fort Fairfield areas, Maine. Fossil locality numbers are those shown on plate 1, except for A which is taken from Boucot and others (1964, p. 32-33).

Perham-Carys Mills contact is also inferred to be gradational as well as locally intertonguing.

As shown earlier, the youngest age that the lower member of the Perham can be assigned is late Wenlock, as determined by the age of the basal part of the upper member of the Perham. The lower member of the Perham appears to disconformably overlie the Pyle Mountain Argillite of Ashgill age along the east flank of the Castle Hill anticline (pl. 1 and fig. 3). Thus, the age of the lower member of the Perham Formation, as bracketed by the ages of the units that enclose it, is Llandovery to middle(?) Wenlock. It is therefore the temporal and laterally eastern facies equivalent of the Llandovery-age part of the Carys Mills Formation. By analogy with the westward-thinning nature of the Carys Mills in the Bridgewater quadrangle, the Carys Mills is believed to have wedged out westward into the lower member of the Perham (fig. 3).

Whereas the lower Perham is, in part, a western facies equivalent of the Carys Mills, the Spragueville Formation is an eastern and more limy facies and, in part, also the temporal equivalent of the Carys Mills Formation. The presence of Zone 19 graptolites (basal Llandovery $B_{1}$ ) near the bottom of the Spragueville at locality 2 is analogous to fossils of similar age found in the Carys Mills and the overlying Smyrna Mills Formation near Smyrna Mills (locs. 28 and 27). West of the Fort Fairfield area, the Spragueville has yielded fossils of late Llandovery $\mathrm{C}_{4}-\mathrm{C}_{5}$ age. Also, from the Presque Isle area westward to Mapleton, the Spragueville lies between the Carys Mills Formation 
and the lower member of the Perham but is absent from this stratigraphic position north of Mapleton. Just west of Mapleton, it seems to end, possibly through a combination of stratigraphic wedging out and because of faulting. In view of these distribution and age relationships of the Spragueville, it is believed to be an eastern, more offshore equivalent of both the upper part of the Carys Mills and somewhat higher stratigraphic levels of the lower member of the Perham. It appears to thin westward progressively as it becomes younger (fig. 3).

The Frenchville Formation, a lenticular unit composed chiefly of graywacke and conglomerate, contains fossils in the interval of $\mathrm{C}_{4}-\mathrm{C}_{5}$ of the upper Llandovery (Boucot and others, 1964, p. 32-33). Hence, it is the near-shore temporal equivalent of the Spragueville and parts of the lower member of the Perham, a relationship schematically illustrated in figure 3.

\section{TACONIC OROGENY}

The Taconic orogeny began to affect the region along the AroostookMatapedia limestone belt in the early Llandovery when uplift, peripheral to the depositional belt of ribbon limestones of the Carys Mills Formation and its equivalents to the north, began to take place and change the nature of the sedimentation in the basin. This uplift is represented by the gradational nature of the change in lithology from the Carys Mills Formation (limy rocks) to the Smyrna Mills Formation (detrital rocks) in the Houlton-Smyrna Mills area (Pavlides and Berry, 1966, p. B53). The change in sedimentation from the Carys Mills to the lower member of the Perham is of similar significance and represents the first effects of uplift of the Taconic orogeny. The greatest uplift of the Taconic orogeny in this part of the northern Appalachians was probably achieved during Frenchville time (Llandovery $\mathrm{C}_{4}-\mathrm{C}_{5}$ ) when the anticlines described above and other Ordovician terrane were uplifted locally to a level where they were able to shed the relatively coarse clastic debris now found in the Frenchville and its equivalents. The general facies relationships seaward, from west to east, of the Frenchville Formation, the lower member of the Perham Formation, and the Spragueville Formation are generalized in figure 3.

Little is known at present of the facies relationships along the east margin of the Carys Mills Formation outcrop belt. The geology in New Brunswick shown on plate 1 was based on reconnaissance (Pavlides, 1966a) ; time did not permit extensive searching for fossils that would supply the same biostratigraphic control now available to the west, in Maine. In general, the clastic sedimentation of the Smyrna Mills and Perham Formations undoubtedly has its counterparts in some of the terrane of undivided rocks along the east side of the Carys 
Mills Formation in New Brunswick. The precise age and facies relationships of these units to their counterparts in Maine, as well as their relationship to the Taconic orogeny, however, cannot be deduced from the information now available in this region.

\section{REFERENCES}

Anderson, F. D., 1954a, Preliminary map, Woodstock, Carleton County, New Brunswick: Canada Geol. Survey Paper 53-33, 3 p.

1954b, Manganese deposits of the Woodstock area, New Brunswick: Canada Geol. Survey Topical Rept. 1, 17 p.

1956, Coldstream-Carleton and York Counties, New Brunswick: Canada Geol. Survey Paper 55-29, map.

Anderson, F. D., and Poole, W. H., 1959, Geology, Woodstock-Fredericton-York, Carleton, Sunbury and Northumberland Counties, New Brunswick: Canada Geol. Survey Map 37-1959.

Beland, Jacques, 1958, Preliminary report on the Oak Bay area: Quebec Dept. Mines Prelim. Rept. 375, 12 p.

1960, Preliminary report on Rimouski-Matapedia area: Quebec Dept. Mines Prelim. Rept. 430, 18 p.

Boucot, A. J., 1961, Stratigraphy of the Moose River synclinorium, Maine: U.S. Geol. Survey Bull. 1111-E, p. 153-188.

Boucot, A. J., Field, M. T., Fletcher, Raymond, Forbes, W. H., Naylor, R. S., and Pavlides, Louis, 1964, Reconnaissance bedrock geology of the Presque Isle quadrangle, Maine: Maine Geol. Survey Quad. Mapping Ser. 2, $123 \mathrm{p}$.

Caley, J. F., 1936, Geology of the Woodstock area, Carleton and York Counties, New Brunswick : Canada Dept. Mines Mem. 198, 21 p.

Crickmay, G. W., 1932, Evidence of Taconic orogeny in Matapedia Valley, Quebec: Am. Jour. Sci., 5th ser., v. 24, p. 368-386.

Dzulynski, Stanislaw, and Walton, E. K., 1965, Sedimentary features of flysch and graywacke: New York, Elsevier Pub. Co., 274 p.

Elles, G. L., and Wood, E. M. R., 1901-18, Monograph of British graptolites: London, Paleontographical Soc., 539 p., 52 pl.

Ells, R. W., 1876, Report on the iron ore deposits of Carleton County, New Brunswick : Canada Geol. Survey, Rept. Prog. 1874-75, p. 97-104.

Kindle, C. H., 1935, Stratigraphy of southeastern Quebec: Geol. Soc. America Proc. for 1934, p. 354.

Lee, H. A., 1962, Surficial geology of Canterbury, Woodstock, Florenceville and Andover map-areas, York, Carleton and Victoria Counties, New Brunswick: Canada Geol. Survey Paper 62-12, 8 p.

Miller, R. J., 1947, Manganese deposits of Aroostook County, Maine : Maine Geol. Survey Bull. 4, 77 p.

Naylor, R. S., and Boucot, A. J., 1965, Origin and distribution of rocks of Ludlow age (Late Silurian) in the northern Appalachians: Am. Jour. Sci., v. 263, p. 153-169.

Neuman, R. B., 1962, The Grand Pitch Formation: new name for the Grand Falls Formation (Cambrian?) in northeastern Maine: Am. Jour. Sci., v. 260, p. 794-797.

Parlides, Louis, 1962, Geology and manganese deposits of the Maple and Hovey Mountains area, Aroostook County, Maine: U.S. Geol. Survey Prof. Paper $362,116 \mathrm{p}$. 
Pavlides, Louis, 1964. The Hovey Group in northeastern Maine: U.S. Geol. Survey Bull. 1194-B, p. B1-B6.

1965, Geology of the Bridgewater quadrangle, Maine: U.S. Geol. Survey Bull. 1206, 72 p.

1966a, Reconnaissance map of bedrock geology of a part of northwestern New Brunswick, Canada: U.S. Geol. Survey open-file rept., scale $1: 250,000$. 1966b, Meduxnekeag Group and Spragueville Formation of Aroostook County, northeast Maine, in Cohee, G. V., and West, W. S., Changes in stratigraphic nomenclature by the U.S. Geological Survey, 1965: U.S. Geol. Survey Bull. 1244-A, p. A52-A57.

Pavlides, Louis, and Berry, W. B. N., 1966, Graptolite-bearing Silurian rocks of the Houlton-Smyrna Mills area, Aroostook County, Maine: U.S. Geol. Survey Prof. Paper 550-B, p. B51-B61.

Pavlides, Louis, and Canney, F. C., 1964, Geological and geochemical reconnaissance, southern part of the Smyrna Mills quadrangle, Aroostook County, Maine: U.S. Geol. Survey Prof. Paper 475-D, p. D96-D99.

Pavlides, Louis, Mencher, Ely, Naylor, R. S., and Boucot, A. J., 1964, Outline of the stratigraphic and tectonic features of northeastern Maine: U.S. Geol. Survey Prof. Paper 501-C, p. C28-C38.

Schopf, J. M., 1964, Middle Devonian plant fossils from northern Maine: U.S. Geol. Survey Prof. Paper 550-D, p. D43-D49.

Schuchert, Charles, and Cooper, G. A., 1930, Upper Ordovician and lower Devonian stratigraphy and paleontology of Perce, Quebec: Am. Jour. Sci., 5th sec., v. 20, p. 161-176.

Stumm, E. C., 1962, Silurian corals from the Moose River synclinorium, Maine: U.S. Geol. Survey Prof. Paper 430-A, p. 1-9 [1963].

Twenhofel, W. H., 1941, The Silurian of Aroostook County, northern Maine: Jour. Paleontology, v. 15, p. 166-174.

White, W. S., 1943, Occurrence of manganese in eastern Aroostook County, Maine: U.S. Geol. Survey Bull. 940-E, p. 125-161.

Williams, H. S., and Gregory, H. E., 1900, Contributions to the geology of Maine: U.S. Geol. Survey Bull. 165, 212 p. 


\section{INDEX}

[Italic page numbers indicate major references]

A

Acknowledgments.

acutus, Orthograptus calcaratus

Age, Aroostook Limestone

Burnt Brook Formation

Carys Mills Formation.

Chandler Ridge Formation

Frenchville Formation.

member

Spragueville Formation................ 15,17

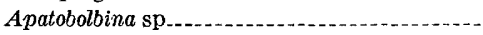

approximatus approximatus, Rastrites ......... arcuaria, Isorthis.

Arenite

Aroostook Limestone.

lower slate and calcareous slate member 14,18

middle ribbon limestone member....... 2, 6, 14

upper nubbly limestone member. .......

Aroostook-Matapedia anticlinorium _ 2, 4, 6, 27, 34, 35

Aroostook River.

Ashland, New Brunswick

Ashland quadrangle.

Atrypa reticularis.

Aulacopleura (Aulacopleura) konincli

\section{$\mathrm{B}$}

Bell Brook Formation

slate member.

Berry, W.B.N., quoted ___ 17,27,35

bicornis, Climacograptus....._._._._._._. 24, 26

bimucronatus, Hallograptus.................. 25

blumenbachi, Calymene...................... 31

bohemicus, Monograptus.................. 30

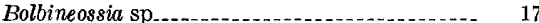

Boucot, A. J., and others, quoted ...... 16, 18, 19, 29 Brachiopods.................. 4, 9, 17, 25, 26, 29, 33 Bridgewater, Maine_...................... 28, 32, 34 Bridgewater quadrangle _............. 7,9,11,32, 37 Bristol, New Brunswick................. 34 Bryozoans -........................ 9 Burnt Brook Formation................. 10, 11, 29

C

calcaratus acutus, Orthograptus.

Calymene blumenbachi

Cambrian to Pennsylvanian rocks (undifferentiated)

Cambrian to Silurian rocks (undifferentiated).

Caribou quadrangle.

Carlingford, New Brunswick

Carys Mills, Maine.
Page Carys Mills Formation _. 2,6, 7, 8, 11, 14, 20, 28, 30, 34 ribbon limestone...................... 35, 38 structure

Carys Mills-Perham contact................ 20, 36

Carys Mills-Smyrna Mills contact. ... _....... 11, 36

Carys Mills-Spragueville contact............ 36

Castle Hill anticline _..._............ 20, 24, 26, 34, 36

Chandler Ridge. ............................. 8

Chandler Ridge Formation _.......... 7,10

Chapman Sandstone................ 33

chimaera, Monograptus................. 30

Chonetes sp................................ 29

Climacograptus bicornis_..._._._._....... 24, 26 eximius.............. 24

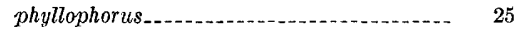

scalaris

miserabilis_._._._._._._. 17

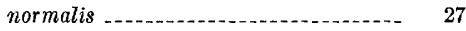

sp

Coelospria saffordi........ 17

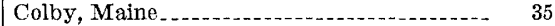

Coldstream, New Brunswick ........... 3

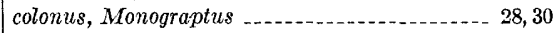

compactus, Monograptus....._._._._. 27, 28, 30

communis, Monograptus............... 17

compactus, Monograptus colonus_._-_._. 27, 28,30

Conchidium

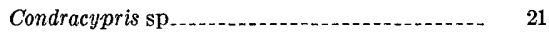

Conodonts......... 32

Contact, Carys Mills-Perham. 20,36

Carys Mills-Smyrna Mills................. 11

Carys Mills-Spragueville _............. $\quad 36$

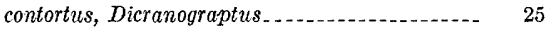

contus, Monograptus tumescens..............- 28

Corals............ 28

crinitus, Monograptus.................... 30

Crinoidal debris............................... 22, 31

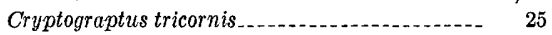

Cumming, L. M., quoted ................ 32

Cystoid plates.................................... 31

D

Dalejina sp

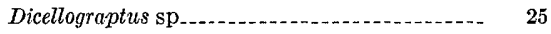

Dicoelosia sp_..._.......... 17

Dicranograptus contortus..................... 25

Didymograptus sagitticaulis_.................. 25

$\mathrm{sp}$

Dikes_.

Diplograptus sp............................ 25

Dockendorff Group

30 dubius, Monograptus _................... 27, 28, 30

8 Dunn Brook Formation............... 23, 24, 29, 33 
Page $\mid$ Lindsay, New Brunswick Pag

Edmunds Hill Andesite.

33 Listerville, New Brunswick................ 22, 30

euglyphus, Glyptograptus

exilis, Nemagraptus

Lithology, Burnt Brook Formation ........... 11

eximius, Climacograptus. Carys Mills Formation................ 8

\section{F}

Facies relationships, Ordovician Silurian

Faulting

Favosites (Astrocerium) intermittens magnum. forbesi, Monograptus.

Fort Fairfield, Maine

Fort Fairfield quadrangle.

Frenchville Formation. $19,26,38$

G

Gaspé Peninsula

Gastropods, platyceratid.

Glacial drift.

Glassia sp.

Glossograptus sp.

Glyptograptus euglyphus................. teretiusculus sp.

gracilis, Nemagraptus

Grammolomatella $\mathrm{sp}$

Grand Pitch Formation

Graptolites. $4,10,24,25,27,29,36$

H

Hallograptus bimucronatus

Hardwood Mountain Formation. ..............

Hedgehog Formation.

Heliolites interstinctus occidentalis. ................

Hodgdon, Maine

25,35

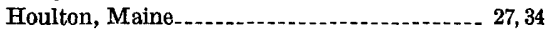

Houlton quadrangle $\ldots . . . . . . . . . . . . . . . . . .7,8,10,32$

Houlton-Smyrna Mills area, Maine

Hovey Hill, Maine_................ 25, 35

Howard Brook, New Brunswick............ 31

Howe Brook

Howe Brook quadrangle................. 24, 33, 35

Howe Brook Stream .......................... 29

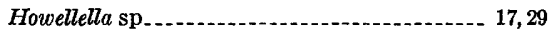

\section{I}

inflata, Zygobolba.

intermedius, Orthograptus truncatus.

intermittens magnum, Favosites (Astrocerium)

interstinctus occidentalis, Heliolites.

Introduction

Isorthis arcuaria.

$$
\mathrm{sp} \text {. }
$$

\section{K}

Knowlesville, New Brunswick.

konincki, Aulacopleura (Aulacopleura)

\section{$\mathbf{L}$}

Leptaena rhomboidalis Leptograptus sp.
Chandler Ridge Formation............... 8

Frenchville Formation.................. 26

Maple Mountain Formation............. $\quad 29$

Mapleton Sandstone.................... 32

Ordovician rocks, Pyle Mountain Argillite.

undivided.

Perham Formation, lower member..... 19

Spragueville Formation................. 16

Littleton Ridge................................. 33

Locality 1 . . . . .

$2 \ldots$

3...

4.

5 .

$6 \ldots$

$11 \ldots$

$12 \ldots \ldots$

13 .

$14 \ldots \ldots$

$15 \ldots$

$16 \ldots \ldots$

$17 \ldots \ldots$

$18 \ldots \ldots$

19 A

$20 \ldots$

21 . 32

$22 \ldots \ldots$

23 .

$24 \ldots$

$26 \ldots$

27 .

$28 \ldots \ldots \ldots \ldots, 11,20,36,37$

$31 \ldots$

$33 . .+\ldots$

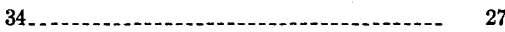

$36 \ldots+\ldots$

$37 \ldots$

Lower member, Aroostook Limestone........ 14, 18

\section{M}

magnum, Favosites (Astrocerium) intermittens. 28 Manganese deposits ..................... 19, 29, 31 Maple Mountain Formation ..._..._..._._. 11, 28 Mapleton, Maine............ 19,34

Mapleton Sandstone........................ 23, 32

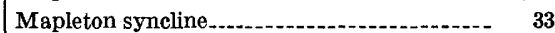

Mars Hill area, Maine........................... 22

Mars Hill, Maine. ......... 29, 31, 34

Mars Hill monadnock

Mars Hill quadrangle....................... 7

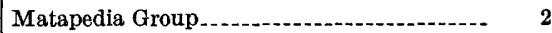

Meduxnekeag Formation.

ribbon rock'member.................... 2,6,8

slate and graywacke member............ $\quad 7$

slate member-.-.......................... 11

Meduxnekeag Group....................... 7

17 Melville, New Brunswick

25,26 Mesopholidostrophia sp_........................ 17 


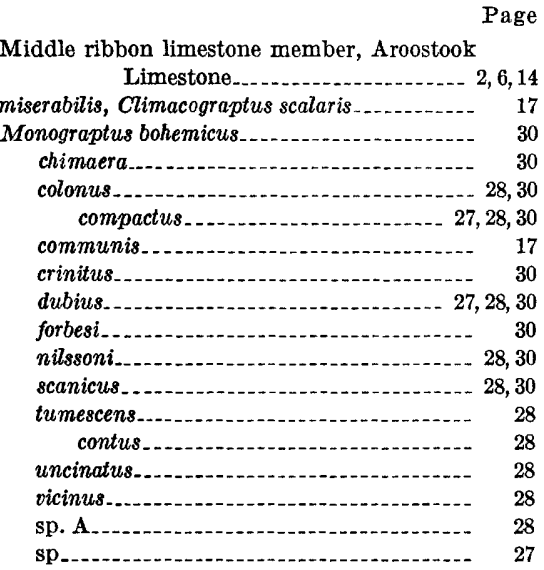

Monticello, Maine.

$\mathrm{N}$

Nemagraptus exilis gracilis.

Neuman, R. B., quoted.

nilssoni, Monograptus.

Nine Lake Formation

normalis, Climacograptus scalaris

Nucleospira sp

\section{0}

Oakfield, Maine

Oakland, New Brunswick.

Ordovician rocks, Pyle Mountain Argillite undivided

Orthograptus calcaratus acutus truncatus intermedius.

Orthotetacid indet.

Ostracodes

Pabos Formation

Palmer, A. R., quoted

Peel, New Brunswick.

Pelmatazoan debris

Perce, Quebec

Perham Formation.

lower member

upper member.

(1) 24

Perth, New Brunswick

phyllophorus, Climacograptus.

Plectodonta sp.

Plutons

Presque Isle area, Maine.

Presque Isle-Castle Hill area.

Presque Isle fault.

Presque Isle, Maine.

Presque Isle quadrangle

Protathyris sp.

Pyle Mountain Argillite

R

Rastrites

approximatus approximatus............--

Red beds.

\section{Redefined}

formations, Aroostook Limestone (abandoned name) ..........

Spragueville Formation.................. 15

Regional metamorphism

Resserella sp.............................. 17

reticularis, Atrypa.............. 17, 29

rhomboidalis, Leptaena._._._._............ 17

Rhynchonellid indet........................ 18

Ribbon limestone member, Aroostook Limestone.

Ribbon limestones, Carys Mills Formation... 35, 38 Ribbon rock member, Meduxnekeag Formation.............................. 2,6,8

Rishona sp.................................. 21

Riverbank, New Brunswick.................. 31

\section{$\mathrm{S}$}

saffordi, Coelospria........................... 17

sagitticaulis, Didymograptus................ 25 St. John River, New Brunswick.............14, 22, 31 scalaris, Climacograptus..................... 27

miserabilis, Climacograptus_.............. 17

normalis, Climacograptus............ 27

scanicus, Monograptus_..._._._._. 28,30

Seboomook Formation. . . . . . .

Sedimentary features, Carys Mills Formation. $g$

Sheridan Sandstone...................... 26

Silurian and Devonian rocks (undifferentiated)

Slate and calcareous slate member, Aroostook Limestone.

Slate and graywacke member, Meduxnekeag Formation...... 7

Slate member, Bell Brook Formation........ $\quad 32$

Meduxnekeag Formation............... 11

Slaty cleavage._._. 6

Smith Brook................................... 24

Smyrna Mills Formation_.... 2, 9, 11, 20, 23, 26, 27, 31

Smyrna Mills quadrangle................ 7

Sphaerirhynchia sp

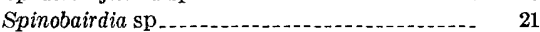

Spragueville Formation ............... 15, 33, 36, 38

Spragueville, Maine.

Stockholm quadrangle

Stratigraphy _.............................. 6

Structure, Carys Mills Formation.......... 22

Swanback Formation..................... 33

\section{$\mathbf{T}$}

Taconic disturbance......................... 14

Taconic orogeny ............................. 38

Tectonic features................ 5

Carys Mills Formation....... $g$

teretiusculus, Glyptograptus._._............ 25

Thickness, Aroostook Limestone............ 10,14

Burnt Brook Formation _............. 7,11

Carys Mills Formation_._._._._._._. 7,10

Chandler Ridge Formation............... $\quad 7,8$

Frenchville Formation. . .

Maple Mountain Formation. . ..._.... $\quad 29$

Ordovician rocks, Pyle Mountian Argillite................................. 25

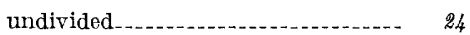

Perham Formation, lower member.....-. 19

Spragueville Formation. .................. 16 


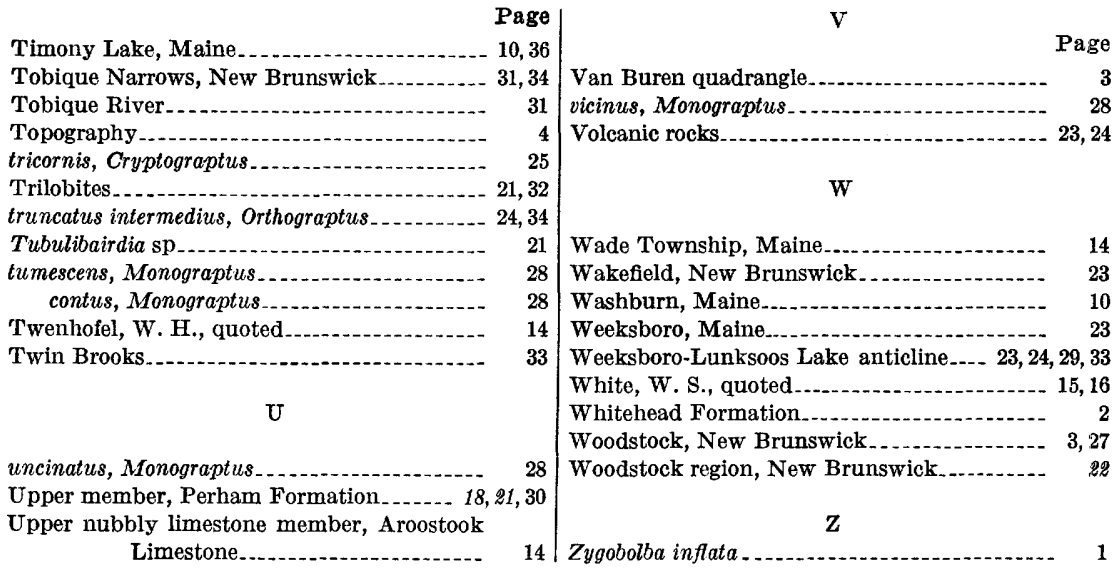

